\title{
3.1. Hacia la construcción de una ciudadanía mediática. Reflexiones sobre la influencia de las políticas neoliberales en la configuración de la comu
}

\section{Mendoza, Marina Gabriela [ver currículum del autor, docente de la Facultad de Diseño y Comunicación]}

Abstract del Proyecto:

El proyecto disciplinar que se presenta a continuación explora, a través de un análisis multicausal, la influencia de la ideología neoliberal en la comunicación política y su incidencia en el proceso de construcción y consolidación de un imaginario de ciudadanía apática y apolítica en la Argentina. En este proceso adquiere una relevancia significativa el estudio del rol desempeñado por los medios de comunicación en tanto que, atravesados por una lógica economicista, han pugnado por la instauración de un modelo publicitario de la política afín a los dictámenes del mercado y responsable de la reducción de la participación ciudadana en la esfera pública, a través de la reproducción mediática de los valores inherentes a esta ideología, y el gradual abandono de una comunicación política garante y protectora de los valores democráticos.

Palabras clave:

comunicación política - liberalismo - ciudadanía.

Introducción

La introducción de la lógica mercantilista en la comunicación política, producto de la instauración del modelo neoliberal en la República Argentina en la década del '90, constituyó uno de los procesos sociales de mayor efectividad que contribuyó a motorizar la guerra cultural iniciada desde el Consenso de Washington en pos de la cristalización de un imaginario que pugnara por el abandono de la utopía de la emancipación latinoamericana.

\section{Cuadernos del Centro de Estudios de} Diseño y Comunicación Nํ 63

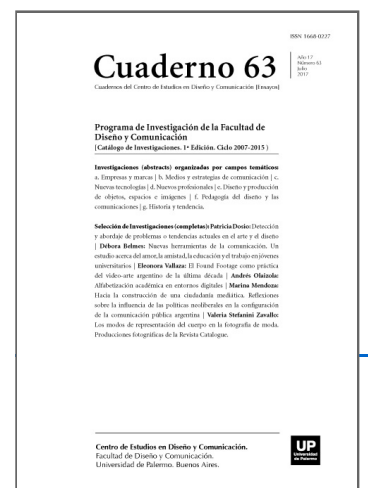

ISSN: 1668-0227

Programa de

Investigación de la

Facultad de Diseño y

Comunicación

Año XVII, Julio 2017, Buenos Aires,

Argentina | 352 páginas

Ver todos los libros de la publicación

compartir en Facebook

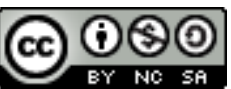

Esta obra está bajo una Licencia Creative Compartirlgual 4.0 Internacional descargar PDF ver índice de la publicación Commons Atribución-NoComercial- 
En este contexto, el ejercicio comunicativo público y político, comprendido no sólo como un medio para canalizar las prácticas discursivas de los estamentos gubernamentales, sino también y especialmente, como vía de información e interpelación hacia el poder desde la ciudadanía, aparece reconfigurado por la ideología neoliberal. Es así como se asiste a un despliegue del ejercicio comunicativo que dista de conceder derechos vinculados con la participación en la esfera pública y la intervención en la toma de decisiones que atañen a la población en su totalidad.

La implementación de políticas neoliberales en el contexto argentino desde la década del '90, ha sido objeto de debate desde múltiples abordajes, con especial hincapié en sus efectos nocivos sobre la desigualdad y la pobreza que la región latinoamericana ha experimentado como producto de su avasallamiento sobre la soberanía de cada nación. Desde una perspectiva filosófico-sociológica, Historia y crítica de la opinión pública (1962) de Jurgen Habermas constituye una obra fundamental para aproximarse a la problemática originada por la introducción en los medios de comunicación de la comercialización de espacios. Habermas plantea, ya en el siglo XIX, que la prensa se torna manipulable de acuerdo con el grado de mercantilización, convirtiéndose en defensora de intereses privados sectoriales.

En el ámbito específicamente comunicacional, aportes como el de Phillippe Breton Medios, mediación, democracia (1998) en torno a la mediación comunicativa que se impone cada vez con mayor incidencia en detrimento del mensaje propiamente político, resultan útiles a los objetivos del presente escrito, en tanto postula que ello deviene en una práctica obstaculizadora del enriquecimiento democrático.

El artículo de Norbert Lechner La política ya no es lo que fue (1996), adopta una clave de análisis más abarcativa, al referirse a procesos sociales de visibilidad en la región latinoamericana y, particularmente, a la transformación de la esfera política. En efecto, sostiene que la mercantilización de las relaciones sociales alcanza también a los procesos de comunicación, alterando la idea de política tal como se la comprendía con anterioridad.

Las reflexiones que Pierre Bourdieu efectúa en sus artículos Sobre la televisión y El campo periodístico y la televisión (1996) constituyen un marco teórico imprescindible para comprender los procesos de lucha que se suscitan al interior del campo televisivo y emprender, asimismo, un análisis pormenorizado de la constitución del sistema mediático argentino, reconociendo los actores sociales intervinientes, el despliegue de estrategias de conservación y subversión y el flujo de capitales que circulan en su interior.

En relación con lo antedicho, es posible sostener que, dentro del campo de los estudios de comunicación y política, el vínculo entre mercantilización de la información y perjuicio de la democracia ha sido evidenciado, aunque con ciertas limitaciones provenientes de su centralización en grupos sociales diferentes al caso argentino, o en una esfera de análisis reducida que excluye lo comunicacional.

La presente investigación se propone indagar acerca de la incidencia que la introducción de la lógica mercantilista en la comunicación política pudiera haber suscitado en el pasaje de una comunicación pública orientada hacia un ciudadano comprometido con el cambio social, a un paradigma comunicativo atravesado por el mero afán de lucro con el consecuente intento de construcción de un modelo de ciudadano espectador del juego público-político. 
En pos de hacer explícita la tensión entre dos modelos de comunicación erigidos en torno a intereses divergentes, el escrito propone un recorrido histórico que abarca desde la consolidación de la ideología neoliberal en el escenario social de la Argentina, durante la primera presidencia de Carlos S. Menem (19891995), y la actualidad, haciendo especial hincapié en la primera intendencia de Mauricio Macri (2007-2011).

Es menester de este proyecto advertir, a través de un enfoque multicausal, las prácticas desplegadas en torno al ejercicio comunicativo que, de la mano de la implementación de las políticas neoliberales, derivaron en un vaciamiento de la noción de comunicación y espacio público. En este sentido, se pondrá especial énfasis en las implicancias que dicha reconfiguración del ciudadano comprometido al ciudadano mediático, pudieran suscitar para la preservación del status quo, por su capacidad de estimular la pérdida de un área sustancial de los regímenes democráticos.

Su intención supera los límites teóricos para ubicarse en el plano social -en el ámbito de las luchas de poder y los conflictos sociales-, contribuyendo a la comprensión de procesos de cuyo desconocimiento se benefician los estamentos de poder hegemónicos para que su discurso resulte naturalizado y legitimado. El carácter propositivo y performativo del proyecto se ve respaldado por el intento de contribuir al cambio social, mediante la producción de un conocimiento reflexivo que, en definitiva, surja del mismo seno al cual será luego aplicado, esto es, la realidad actual argentina.

La comunicación política como instrumento del ejercicio democrático

La comunicación política es un espacio de intercambio de discursos en el que intervienen tanto el Poder Ejecutivo, los órganos de gobierno, los políticos y funcionarios, como los periodistas, la opinión pública y la ciudadanía que se sirve de estos instrumentos para informarse acerca de los acontecimientos significativos de la sociedad.

En este sentido, la comunicación política detenta un poderío significativo en la esfera social. En tanto contribuye al logro de transformaciones a nivel perceptual y actitudinal, se erige en una de las principales y más eficaces fuerzas de cristalización de representaciones, imaginarios y subjetividades diversas.

La valorización de la práctica comunicativa como un servicio a la comunidad permite advertir la intrínseca vinculación de los procesos sociales, políticos y económicos con la producción de discursividades. En efecto, las posibilidades emancipatorias que el buen uso de la comunicación implica para la construcción de una ciudadanía participativa, constituye al mismo tiempo y paradójicamente, su principal obstáculo.

Para Robert White (2007), el rol del comunicador público, desde una perspectiva ética del ejercicio profesional, implica "defender y extender el derecho de la gente a participar en el gobierno del país, en cada esfera de la vida. Una buena democracia debe estar fundada en principios éticos" (p. 8).

El ejercicio comunicativo comprendido desde un enfoque participativo busca promover la intervinculación entre ciudadanos y funcionarios de gobierno, estableciendo entre ellos lazos de mutua reciprocidad. Esto implica desplegar canales de participación a través de los cuales sea posible intervenir en la toma de decisiones, para instalar o modificar medidas que requieran ser adoptadas en función de las necesidades sociales. 
Es inherente a la práctica comunicativa el impulso de vías de realimentación entre actores que se encuentran en una situación de mutua interdependencia; de un lado, funcionarios con necesidad de legitimar una gestión de gobierno; del otro, ciudadanos que se nutren de las comunicaciones gubernamentales para inteligir su propia cotidianeidad, y contribuir a su mejora.

Desde esta perspectiva, se considera a la comunicación política como un área esencial del ejercicio ciudadano, potencialmente capaz de funcionar más que como órgano de difusión de los actos y discursos gubernamentales, como un ámbito de canalización de las necesidades de la población para interpelar ese poder por vías adecuadas.

En este contexto, los medios de comunicación ejercerían una función de instrumentos de información bifronte, ejerciendo el rol de mediadores en el proceso de comunicación pú- blico-política. Las tesis que postulan a la información como un medio eficaz para fomentar la educación para la participación ciudadana, argumentan que informar es sinónimo de elegir, a través del conocimiento pormenorizado de los distintos medios disponibles, creer o refutar la veracidad de las opiniones emitidas por los organismos responsables de la información pública.

De ello se desprende que la responsabilidad por las informaciones emitidas representa un compromiso al que deben responder los medios, en respuesta al derecho irrestricto que posee la ciudadanía de acceder al conocimiento de los eventos significativos de la vida social. Estimular una ciudadanía mediática social -el uso de las tecnologías de la información y la comunicación en favor de la ampliación de derechos-implica democratizar las comunicaciones para construir nuevas formas de canalización de las necesidades de participación e inclusión de vastos sectores de la población. La comunicación social, comprendida como un medio de canalización e intervinculación, posee una gran capacidad de crear fondos de actitudes favorables para lograr cambios en las percepciones que se desea vincular a determinada idea, organización o personalidad pública. En el contexto de un país, la información es una herramienta fundamental que se erige como potencial impulsora del cambio social, en tanto viabiliza la concreción de metas, aspiraciones y propósitos que no sería posible obtener sin su efectiva intermediación. Iniciativas similares al modelo propuesto han sido implementadas durante la década del '70 en el marco de las denominadas Políticas Nacionales de Comunicación, incluso en algunos países latinoamericanos, como Venezuela y México. Emprender una política comunicacional tendiente a introducir en el debate la necesidad de democratizar los medios y canales de comunicación, instalaba en la esfera de discusión de aquellos países una temprana preocupación por "el servicio público, el acceso a la información y la participación, la condena al desequilibrio en el flujo informativa internacional; el derecho a la información y el derecho a réplica" (Becerra y Mastrini, 2001).

El fracaso de estas iniciativas en la década siguiente no respondió a la inviabilidad de sus propuestas, sino a la necesidad de instaurar un nuevo orden mundial económico y político dominado por la dictadura del mercado en el que las comunicaciones -en su vertiente mercantilizada- asumirían un rol protagónico, decisivo para la historia de América Latina. Otras perspectivas teóricas abordan las ventajas que supondría la conversión de las cadenas de televisión generalistas en organizaciones públicas, actuando como esferas centrales. A este núcleo medular lo rodearían cuatro sectores periféricos -sector cívico, sector profesional, sector de empresas privadas y sector de los medios privados-, manteniendo una relación de diálogo e intercambio recíproco permanente, y conectando los grupos periféricos con la esfera central. 
Lo interesante de esta propuesta es que plantea la posibilidad de que la sociedad civil desarrolle medios o programas imbuidos de su realidad cotidiana, y concentrados en un interés o problemática particular de un grupo, movimiento social o sindicato. (Curran, 1991, pp. 105-111) No es menester de este proyecto postular una visión ingenua de un tiempo otro de la comunicación en el que los medios hubieran ejercido el rol de garantes de la libertad de expresión. Lo que se propone es adoptar una mirada histórica sobre el proceso de convergencia de capitalismo y concentración en la lógica comunicativa, para comprender las circunstancias sociales que derivaron en la consolidación de un modelo cultural hegemó- nico que sustenta su dominación sobre la alineación de lo que deberían ser instrumentos de intervinculación entre ciudadanos y gobernantes.

Guía este proyecto la intención de analizar las circunstancias históricas que han posibilitado la instauración de un modelo de ciudadanía concebido para obedecer los mandatos del mercado, sostenido por una ilusión de participación generada por la multiplicación de medios y soportes de comunicación, y un discurso ideológico construido para su consolidación.

El análisis no recaerá, por ello, en los medios de comunicación, sino en "las mediaciones sociales (...) el modo en el que la gente produce el sentido de su vida, el modo en que se comunican y usan los medios" (Martín Barbero, 2010). Los cambios producidos a nivel de la subjetividad y el gradual abandono de los imaginarios sociales de emancipación y transformación social, constituyen la antesala de la consagración del modelo de ciudadanoconsumidor, erigido en torno a la naturalización de la lógica del mercado y la constitución de un saber privatizador de la esfera pública.

Entre el proceso y la transición: la ideología neoliberal

La dictadura institucional de las Fuerzas Armadas erigida en poder dominante durante la década del '70, y el golpe de Estado represivo que impusieron durante siete años los militares Videla, Massera y Agosti, respondieron a la necesidad de instaurar un nuevo orden en América Latina. Evidenciando el desarrollo de circunstancias propias de estas latitudes - populismos, revoluciones, fortalecimiento de los movimientos sociales- se asumió la imperiosa necesidad, por parte del centro hegemónico capitalista mundial, de disponer la región al servicio de su propio beneficio.

Siguiendo las tesis de Ansaldi en Matriuskas de terror (2004), su imposición en América Latina durante la década del '60 y '70 se orientó a "corregir los vicios de la democracia"; ya fuera que adoptase la forma del populismo, como en los casos de Brasil y Argentina, el reformismo socialista, como en Chile, o la amenaza potencial de la izquierda revolucionaria presente en organizaciones de base de Uruguay y Argentina.

En efecto, los dictadores, ante la ausencia de legitimidad propia, tendieron a autofundamentarse en lo que su misma práctica restringía, la democracia, sosteniendo que su intervención respondía a la necesidad de restaurar las democracias conculcadas por las prácticas corruptas, demagógicas y degeneradoras de los políticos que habían creado el clima propicio para la penetración de la subversión marxista, o bien para instaurar una nueva democracia.

La desestructuración del orden previo, caracterizado por los logros del modelo de sustitución de importaciones y el intervencionismo de Estado en la distribución progresiva del ingreso, el incremento en los niveles de 
ciudadanía -incluyendo ahora la percepción de derechos-, el aumento del gasto público y la mejora en la calidad de vida, constituyó un retroceso no sólo económico, sino también social.

El proyecto de inauguración de un nuevo período en la historia argentina quedó forjado en las palabras del dictador Jorge Rafael Videla a pocos días de iniciado el golpe: Debe quedar claro que los hechos acaecidos el 24 de marzo de 1976, no materializan solamente la caída de un gobierno. Significan, por el contrario, el cierre definitivo de un ciclo histórico, la apertura de uno nuevo, estará dada por la tarea de reorganizar la Nación, emprendida con real vocación de servicio por las FFAA. (D Andrea Mohr, 1999) Las dictaduras institucionales latinoamericanas irrumpieron en la escena regional para trocar un sistema político amenazador en un sistema estable donde resultara impensable la revolución del status quo. En el plano económico, resultaron funcionales a la necesidad de un cambio en el patrón de acumulación, sustentado en el pasaje del modelo de sustitución de importaciones por el modelo de valorización financiera, que establecía nuevas funciones para los países de la región.

En el plano cultural, la Doctrina de la Seguridad Nacional se orientó a tender puentes entre la necesidad de expansión mundial del capitalismo y la naturalización de la obediencia y la sumisión necesarias para aceptar la cancelación del eterno sueño de liberación latinoamericana. La Doctrina de Seguridad Nacional efectivizó el cierre de un período de cambio y potencial superación de la situación de dependencia con los centros dominantes, garantizando la despolitización, la marginación y la represión de los ciudadanos.

En Argentina, la dictadura "sirvió a los intereses de la gran burguesía (...) aliada al capital extranjero, para los cuales el disciplinamiento de la fuerza de trabajo constituía un objetivo central" (Ansaldi, 2006, p. 101). La creciente participación política de grandes sectores de la población durante los gobiernos peronistas, el crecimiento de organizaciones guerrilleras fuertemente influenciadas por las premisas revolucionarias derivadas de la victoria cubana, y la potencial capacidad ciudadana de incrementar sus formas de intervención política, constituían amenazas que era preciso eliminar.

El proyecto a largo plazo de las dictaduras latinoamericanas consistía en consagrar un imaginario en torno al ejercicio democrático que revelara impracticable e innecesaria la intervención directa en las decisiones públicas, y más aún el trastrocamiento del estado de cosas para la superación del capitalismo. Un imaginario social de conformismo y pasividad, erigido en torno a la armonía política lograda gracias a una democracia estable y ordenada -aún cuando eso requiriese el empleo de las fuerzas represivas-.

La lógica mercantilista que se impuso como consecuencia en todas las esferas sociales, pregonando al individuo autónomo y libre para orientar sus propios intereses hacia fines exitosos, convergió con un imaginario de conservación y miedo al cambio, provocando la ruptura de lazos sociales de cohesión elementales para el ejercicio de una ciudadanía democrática. En efecto; "la fragmentación social dificulta la (re)constitución de identidades colectivas y potencia, en el mejor de los casos, las representaciones segmentadas, puramente sectoriales; en el peor, en cambio, abre camino a la anomia". (Ansaldi, 1995, p. 21) La ruptura de las vías de comunicación entre la sociedad y sus gobernantes, implicó un deterioro del ejercicio democrático, obstaculizando la necesaria reciprocidad entre uno y otro actor. En un contexto tal, no resulta difícil advertir la facilidad con la que resultó admitido y consagrado un modelo de ciudadano individualista, que pregona por sus propios intereses en el marco de una sociedad atravesada por la lógica mercantilista y debilitada en sus vínculos de cohesión. 
Ello permite pensar al proceso de instauración de una comunicación política erigida en base a un paradigma comercializable de un modo incipiente en el mismo período de instauración de las dictaduras latinoamericanas, mediante la contribución de la cobertura ideológica de la Doctrina de la Seguridad Nacional y la doctrina económica neoliberal.

Si, como sostiene Robert White (2007, p. 60), "comunicar es en gran parte fundar la realidad tal cual es, haciéndola propia, modificándola", las fuerzas hegemónicas de la década del '70, por vía de los militares latinoamericanos, monopolizaron el relato para naturalizar una visión de mundo afín a los intereses capitalistas, presentándolo como inmutable, inexorable y beneficioso para la humanidad toda, y postulando el cambio, la revolución y el conflicto social como elementos perjudiciales para la emancipación ciudadana.

La irrupción del modelo neoliberal: implicancias en la comunicación

Es posible evidenciar, en función de lo antedicho, que las implicancias de la revolución neoliberal son susceptibles de evidenciarse en áreas no sólo económicas o políticas, sino también comunicacionales.

En tanto la ideología neoliberal pugnó por la espectacularización de la política y la gradual transformación del ciudadano comprendido como potencial instrumentador del cambio social en un mero espectador, tornó impensable la posibilidad de ejercer el derecho a la participación activa en la toma de decisiones políticas mediante los instrumentos mediáticos. La mirada socio-histórica que se propone en esta instancia exige un cuestionamiento de ese modelo de ciudadano espectador que permita derribar su apariencia de ciudadano ideal.

Si bien la década del '90 representa el auge de la revolución neoliberal, es durante los primeros años del menemismo (1989-1995) que la espectacularidad de la política y la gradual transformación del ciudadano en un espectador pasivo del juego pseudo democrático, logran subvertir las formas de percibir el derecho a la participación activa en la política. El discurso que operó sobre gran parte de la ciudadanía durante la primera presidencia de Carlos S. Menem, ofrecía una lectura de la gestión pública como inútil e ineficaz que se contraponía completamente a la administración privada, presentada como un activo necesario para la práctica gubernativa y acuñada en un individualismo irrestricto.

Ansaldi (1995) sintetiza la orientación del modelo neoliberal bajo cuatro premisas; Centrado en el papel subsidiario del Estado -limitado a la condición de garante de la libertad de mercado, nuevo "ídolo"- la privatización de empresas del sector público, la apertura de la economía (en los sectores productivo, comercial y financiero) y la reasignación de los factores productivos procurando aprovechar las ventajas comparativas que brindarían los recursos naturales de cada país. (p. 7) Las medidas tomadas en pos de la privatización de la vida pública, la erección de barreras obstaculizadoras entre funcionarios de gobierno y ciudadanos, y la expansión de la mentalidad individualista e individualizante, como resultado del giro neoliberal impulsado desde las más altas esferas del poder mundial, comienzan a cristalizar, así, sus efectos no sólo en áreas económicas y políticas de la Argentina sino, especialmente, en el logro de un cambio cultural tendiente a que la población abandonase la posibilidad de concreción de la utopía de la emancipación y la autonomía latinoamericana.

Al augurar la muerte de la política entendida como un compromiso con el cambio social, eliminando al actor político y erigiendo en su lugar al candidato que se instala mediáticamente con la lógica de la imagen, y restando protagonismo, a su vez, al ciudadano como ejecutor de los derechos civiles que la propia democracia le confiere, 
se estableció una suerte de tendencia hacia la despolitización que afectó, y sigue afectando, la capacidad de representación de la población.

La despolitización de la ciudadanía refiere a las múltiples formas de escisión entre la sociedad civil y el espacio político en el que interviene el Estado, los partidos y organizaciones doctrinarias, los políticos y el gobierno. (Rouvier, 2004, p. 155) El auge del modelo neoliberal habría operado, en un mismo movimiento, sobre el reemplazo de la comunicación política como espacio de intercambio de discursos divergentes, por el de una esfera donde lo que importa no es tanto el conocimiento de los candidatos a ejercer cargos públicos por sus propuestas para la propia sociedad en que se insertarán, sino por lo que aparentan en términos de noticiabilidad, carisma, repercusión o impacto. La ideología neoliberal pugna por su legitimación mediante la destrucción de las posibilidades alternativas, erigidas en torno a una comunicación política acorde a su finalidad intrínseca en lo inherente al ejercicio democrático, en pos de un modelo publicitario de la política que reduce o elimina las posibilidades de cambio social, tendiente a la conservación del statu quo.

En este contexto, se entiende por mercantilización mediática: (...) el proceso de market driven journalism o periodismo que sirve al mercado de inversores, anunciantes y fuentes con poder, antes que ( $\mathrm{y}$, a menudo, a costa de) los intereses del público. Las consecuencias son una "pobreza informativa" materializada en el infotainment (fusión de entretenimiento e información) y distorsiones para elevar la atención (que no el conocimiento) de la audiencia, rebajando los costes de producción al máximo. (Barnhurst, Cordeiro y Sampedro, 2003, pp. 220-221) Durante la primera presidencia de Menem, el despliegue de prácticas discursivas excluyentes del ámbito público, y las medidas tendientes a la mediatización de la política, constituyeron estrategias por medio de las cuales se pugnó por posicionar como universal y absoluta una noción de comunicación vaciada de contenido, conservadora del statu quo e irreflexiva, al mismo tiempo que se construía un modelo performativo de ciudadano ideal, característicamente sumiso, pasivo ante el poder político y con un nuevo rol de consumidor que trastocaría la totalidad de su realidad social, alejándolo de la participación democrática y la intervención pública.

Advirtiendo las profundas consecuencias que un cambio de estas características podría promover sobre los procesos democratizadores, al promover un constructo ideológico individualista y segregacionista, Becerra y Mastrini apuntan que "los procesos de exclusión no van a darse ya por la ubicación geográfica solamente, sino principalmente por la capacidad de pago" (2001, p. 10). Concentración mediática, homogeneización del discurso y mediatización de la política constituyen, así, los tres ejes rectores que permiten comprender el triunfo del modelo neoliberal en la esfera de las comunicaciones públicas. Un triunfo que no dependió sólo de variables exógenas sino, y principalmente, de actores nacionales con un profundo interés en su consolidación.

\section{Concentración mediática y reducción de la ciudadanía}

La irrupción del capitalismo en todas las esferas de la vida, con el subsiguiente proceso de concentración y centralización desmedido que caracteriza a los Tiempos Contemporáneos, ha alcanzado, desde hace ya varios años, a los medios de comunicación masivos. Ello requiere reconsiderar el rol de los medios de comunicación; de esferas de conexión entre actores sociales diversos, asumen el rol de organizaciones con fines lucrativos, que detentan la soberanía informativa del espacio mediático nacional. 
La privatización de las comunicaciones constituyó el punto de partida de la concentración mediática, no sólo de carácter geográfica, sino también informativa e ideológica. El trastocamiento del ciudadano participativo en mero ciudadano espectador, precisó de un conjunto de instrumentos que, oportunamente alineados detrás del proyecto capitalista, contribuyesen a postular como universal y necesaria la perspectiva de una clase social hegemónica, con intereses sectoriales y clasistas.

Robert White (2007) advierte en este sentido que los medios de comunicación ya "no son el lugar donde las personas deliberan conjuntamente, libre y responsablemente sobre el futuro de la nación. De hecho, parece no haber ningún lugar donde el público pueda ser convocado para deliberar acerca del futuro". (p. 29) El proyecto privatizador y desregulador de la ideología neoliberal implicó el pasaje de los medios de comunicación del Estado a compañías privadas, en pos de su modernización tecnológica y la mejora de su operatividad. El caso paradigmático lo constituye la privatización de la compañía de telecomunicaciones Entel, efectivizada mediante los decretos 731/89 y 62/70. Colocar en manos de intereses corporativos y, en el caso específico de las telecomunicaciones, provenientes de empresas internacionales que pugnaron por su propio beneficio particular o el de su nación en detrimento de la propia sociedad argentina, constituyó el inicio de la crisis económico-social que estallaría en 2001.

La privatización de las informaciones derivó en un gradual proceso de concentración de las corporaciones mediáticas en manos de un grupo reducido de empresarios con un gran poder de influencia sobre la ciudadanía, que se arrogan la soberanía de una gran porción de los discursos simbólicos emitidos.

De ello se deriva la conformación de un escenario mediático administrado verticalmente y centralizado en unos pocos grupos económicos de residencia en la Capital Federal, desde donde asumen el dominio de la palabra.

Informes efectuados por la Asociación de Diarios del Interior de la República Argentina (ADIRA, 2012) confirman la situación de concentración mediática, advirtiendo que la participación de los medios provinciales en el mercado nacional es de un 58\% entre los editados en Capital Federal, y de un $42 \%$ entre los editados en el interior. Por otra parte, la participación de los diarios de la Capital Federal en el mercado del interior es de un 90\% entre los editados en el interior del país, mientras que el compendio de los editados en Capital Federal, alcanza el $10 \%$.

Si bien la recientemente aprobada Ley de Servicios de Comunicación Audiovisual (2009) significó el acceso a la comunicación de un gran porcentaje de la población, situaciones de desigualdad en el consumo de los instrumentos mediáticos sumadas a la concentración informativa, geográfica e ideológica, continúan ejerciendo una fuerza innegable, detrás de la que se oculta un conjunto social que, mediante el dominio de la palabra, detentan un poderío insoslayable en la cotidianeidad de la población.

La concentración mediática, además de reducir la diversidad del contenido informativo que se proyecta hacia el interior de un grupo social, puede significar un riesgo para la conservación de la democracia. Introduciendo la variable de agenda setting o canalización periodística de la realidad, es posible advertir el impacto que la fijación temática a cargo de los medios de comunicación, regidos por intereses privados en su calidad de corporaciones, genera sobre los discursos-saberes reproducidos que contribuyen a la legitimación del orden. 
La conducción de los debates hacia un conjunto de temáticas de preocupación pública, en detrimento de otras que son excluidas de la discusión nacional, coloca a los medios de comunicación en el papel de decisores fundamentales del relato público. Ello, sumado al poder de cohesión social que se asume posee la opinión pública -trocada en opinión mediática- sobre la aprobación o desaprobación de asuntos de trascendencia nacional, posicionando a los medios de comunicación como vehículos portadores del sentir y el pensar social.

Si bien los medios de comunicación se constituyen en la actualidad como los principales instrumentos de vehiculización de los discursos de actualidad y relevancia nacional, esta pseudo opinión pública dista mucho de representar la pluralidad de discursos que circulan en el espacio público con un cierto grado de cristalización.

No es el proceso de fijación temática el que se intenta cuestionar, en tanto resulta inherente a la constitución misma de los instrumentos de información. Pero es posible advertir que, así como es posible utilizar los medios en pos de intereses corporativistas -incremento de las ventas, mejoras en la rentabilidad-, o sectoriales favoreciendo el conocimiento y la aceptación de un determinado grupo o persona-, subyace la posibilidad de emplear los mecanismos dispuestos para la tematización en función del tratamiento de cuestiones que reconociendo las propias limitaciones del sistema- resulten beneficiosas para los integrantes de una sociedad.

Descentralizar la estructura mediática vigente en la Argentina implica pregonar la conformación de un sistema abierto a opiniones disímiles que, mediante mecanismos democráticos, promueva la participación ciudadana activa y responsable, reconociéndole a la población una capacidad de respuesta e intervención efectiva sobre su realidad.

La lógica economicista introducida en el seno de los medios de comunicación, y su marcada influencia en las formas de representación del ciudadano respecto del rol que ejerce en el marco de una sociedad democrática, sumadas al proceso de concentración mediática, logran consolidar un discurso tendiente a la legitimación del orden dado y la preservación del sector social en ejercicio del poder.

Ello en función de presentarse como escindido de las prácticas sociales que intervienen en su constitución, esto es, ocultando su vinculación a la perspectiva de un grupo determinado que se presenta como universal y absoluto mediante la adopción de una postura neutral y objetiva, trascendente a cualquier condicionamiento social.

La racionalidad exitista y economicista por la que se rigen los medios de comunicación impregna la constitución de imaginarios sociales y representaciones que modelan las formas de interacción social. Las matrices de sentido desde las cuales se comprenden y explican las diversas categorías sociales, ejercen un rol de mediación desde los cuales esos imaginarios se vivencian (Castoriadis, 2007). Es posible advertir así el poder que detentan los medios de comunicación en la era de la imagen y la espectacularidad de la vida.

La privatización de las comunicaciones como política de Estado, en el marco del proceso de desprendimiento de las empresas públicas por parte de la administración menemista, constituyó el puntapié inicial para trastocar definitivamente la idea de un ciudadano participativo a un mero espectador. Su capacidad de subvertir las formas de canalización de las necesidades ciudadanas hasta limitarlas a su mínima expresión refleja su influjo sobre los mecanismos democráticos. 
La década de los noventa le dio su fisonomía decisiva a la revolución neoliberal liquidando, por inactual e inservible, la idea de una ciudadanía integradora y capaz de generar las condiciones para una genuina movilidad social. (...) Nada, o demasiado poco, quedó de aquella otra sociedad articulada desde la lógica de la solidaridad y de la equidad; de aquellas experiencias de ciudadanía que apuntaron a la integración y a la multiplicación de la esfera pública como ámbito de encuentro y de acción transformadora. (Forster, 2012, pp. 7-8) El avasallamiento de los derechos de participación e inclusión en la toma de decisiones públicas mediante el retroceso del Estado en espacios de intervención ciudadana, promovió la reducción de los canales democráticos. En su lugar se erigió el mercado, árbitro indiscutible, a partir de entonces, del juego de inclusión-exclusión de la esfera pública.

La homogeneización del sistema comunicacional

Un efecto palmario de la concentración mediática es la homogeneización de los consumos culturales, consecuencia de la cual se derivan la unificación del discurso y la igualación de las agendas temáticas nacionales e internacionales.

En este proceso de homogeneización asumen un protagonismo decisivo los medios de comunicación, dirigiéndose al público ya no como un conjunto de ciudadanos con pleno derecho a ser informados, sino como potenciales consumidores de los productos y servicios que comercializa el anunciante. (Habermas, 1981) La primacía del mercado y la consagración de la lógica mercantilista en todas las esferas de la vida en sociedad, generó cambios significativos en el imaginario social. Con el objeto de controlar las emisiones de información de los países periféricos y restringir el acceso ciudadano a los canales de participación, el cambio cultural incluyó la transformación de un país heterogéneo y diverso en un mero receptor de la industria cultural hegemónica, y en un fiel reproductor de sus consumos.

Lo anteriormente expuesto remite a variables de larga duración que se remontan a los orí- genes del país como Estado-nación consolidado. La naturalización del sistema consumista y la adopción pasiva y sin cuestionamientos de los productos culturales provenientes del exterior-especialmente de las potencias dominantes- constituyen fieles reflejos del colonialismo cultural que, aún hoy, limita la producción nacional condicionando, incluso, las políticas públicas tendientes a estimularla.

En efecto, la admisión de la industria cultural norteamericana, en su naturalización cotidiana, adquiere un grado de pregnancia irrefutable en el escenario social cuando es promovida desde autoridades gubernamentales, referentes sociales o medios de comunicación que detentan un poder monopólico sobre las informaciones emitidas por el sistema mediático nacional.

La adopción de dichas prácticas, plasmadas en discursividades diversas y ejercidas sobre la afirmación de superioridad de un país frente a otros, contribuye a la consolidación de un modelo homogeneizador que tiende a debilitar los canales de participación de los ciudadanos argentinos, limitando, por consiguiente, la democratización del espacio público-político. Martín Becerra y Guillermo Mastrini (2001) vinculan la homogeneización del sistema comunicacional y los productos culturales consumidos en América Latina con variables estructurales propias del proceso de globalización mundial. Analizando el accionar de cuatro grupos dominantes de distintos países de la región, en clave comparativa, revelan el entramado de poder que vincula las comunicaciones audiovisuales locales con el establecimiento de un modelo panamericano de televisión promovido desde grupos económicos de capitales transnacionales. 
En palabras de los autores: El modelo de televisión latinoamericano comercial y altamente concentrado resultará funcional para desarrollar proyectos vinculados al nuevo lugar que ostentará la comunicación en la economía mundial. (...) los grupos como Televisa, Cisneros, Globo y Clarín dominan el mercado regional y su comportamiento tiene una lógica semejante a la que observan los principales actores corporativos a escala global: son grupos multimedia con ramificaciones a otras actividades comunicacionales centralmente: telecomunicaciones; informática; industria gráfica) pero también a otras ramas de la industria y el comercio. (Becerra y Mastrini, 2001) La caracterización de grupos multimediáticos permite advertir dos fenómenos análogos: el incremento en su capacidad de captación de audiencias, obteniendo índices de rentabilidad marcadamente superiores a los que supondría la explotación de un único medio; y un reforzamiento de su influencia en la instalación de temas, ideas u opiniones en la esfera pública de cada país, al irradiar verticalmente las mismas informaciones en los distintos medios de los que son propietarios.

Estos dispositivos, posicionados como garantes de la información neutral y equitativa, y defensores de una libertad de expresión -que no es más que libertad de empresa-, ocultan en su accionar cotidiano su carácter de organizaciones sin fines de lucro, interesadas en adquirir logros corporativos que les permitan continuar detentando la soberanía informativa para incrementar, de esa forma, su rentabilidad.

La propia lógica mediática prioriza en sus coberturas aquellos sucesos que generan un impacto social significativo. El relato mediático centrado en la morbosidad, el sensacionalismo y la ficcionalización de los hechos cotidianos, es el producto inmediato de la priorización en la tarea informativa de los mandatos del mercado; el minuto a minuto, los índices de audiencia y la maximización del espacio publicitario contra la minimización y pauperización del contenido rigen y reglamentan las comunicaciones desde su privatización.

El discurso mediático así construido, atravesado por la concentración informativa, la uniformización de los mensajes y la hegemonía cultural ejercida por grandes grupos econó- micos que se arrogan el resguardo de la neutralidad y la objetividad de las informaciones, representan la superficie visible de un proceso subyacente promovido por la consolidación de la ideología neoliberal durante los primeros años de la década del '90.

Si bien la evolución de los mercados comunicacionales hacia una lógica transnacional es un fenómeno visible en este período, responde a condicionantes estructurales que pueden rastrearse en períodos previos, cuando las innovaciones tecnológicas y la multiplicación de medios, soportes y canales exigió la modernización de la infraestructura comunicativa nacional, con la consiguiente adopción de los consumos culturales de otras latitudes.

La espectacularización de la vida cotidiana: política y ficcionalidad

En La Sociedad del Espectáculo (1967), Guy Debord analiza las sociedades modernas a la luz de su tendencia a la contemplación de lo espectacular. El espectáculo es, en tanto modelo dominante de estas sociedades, la imagen de la economía capitalista en la que reina la fascinación ante el proceso, en detrimento de la consideración de los fines que se persiguen. Una forma de escisión más que profundiza la alienación del sujeto a favor del objeto contemplado, fruto inconsciente de su propia actividad.

En efecto, el espectador Cuanto más contempla, menos vive; cuanto más acepta reconocerse en las imágenes dominantes de la necesidad menos comprende su propia existencia y su propio deseo. La exterioridad del 
espectáculo respecto del hombre activo se manifiesta en que sus propios gestos ya no son suyos, sino de otro que lo representa. Por eso el espectador no encuentra su lugar en ninguna parte, porque el espectáculo está en todas partes. (Debord, 1967, p. 8) La comunicación política, sustentada sobre las nuevas formas mercantilizadas que asume su ejercicio profesional, se torna espectacular en tanto impulsa y sostiene una lógica basada en la imagen del candidato o de la autoridad en vigencia. Si el espectáculo es la ideología por excelencia que torna real la apariencia mediante la negación de la vida, las formas espectaculares de la política no son otra cosa que la negación de la política, el empobrecimiento de la discusión y el debate públicos y el enajenamiento del hombre en su rol de espectador.

La forma ficcional del Marketing político permite al candidato o autoridad en ejercicio exponer a la ciudadanía sólo aquella faceta que conviene a sus intereses, en una era dominada por el poder de la imagen. Hoy más que nunca, la relación de los sujetos es mediada por imágenes. Los canales de participación democrática no son más que meros subterfugios de opiniones y expectativas predispuestos para aparentar el funcionamiento de las formas representativas de adhesión e intervención política.

En las áreas subdesarrolladas, sostiene Debord, la modernización implica no sólo la adecuación de las estructuras productivas existentes a la última tecnología fabricada en los países centrales, sino también el consumo -inconsciente- de las mercancías organizadas y organizadoras de la apariencia. El consumo cultural homogeneizado y homogeneizante torna verídica la reificación de la vida cotidiana, en la que las cosas son las dueñas de la vida social, al mismo tiempo que concretiza las formas aparentes del idealismo que se presentan en la pantalla de televisión, o se narran en los periódicos y programas radiales. La presencia efectiva de la falsedad garantiza la dictadura de lo aparente, al excluir la praxis y, con ello, a los actores como sujetos activos que construyen, rechazan, subvierten o aceptan el mundo social. La sociedad espectacularizada no es otra cosa que "la eliminación de los límites entre el yo y el mundo mediante el aplastamiento del yo asediado por la presenciaausencia del mundo", y su consecuente reemplazo por hechos sociales alucinatorios. Una sociedad en la que la dificultad de reconocerse mutuamente como actores sociales deviene en una imposibilidad de reconocer su propia realidad circundante. (Debord, 1967, p. 64) En un contexto social que promueve y garantiza la escisión del actor de su propia capacidad de reflexión y participación en la esfera pública, no resulta arduo comprender la gradual ficcionalización de la actividad política y, en consecuencia, de la comunicación que de ella se deriva. En efecto, la ficcionalización de la política se sustenta en dos pilares básicos: la banalización constante de la participación ciudadana y la espectacularización de los contendientes políticos, sus actos, discursos y acciones.

La banalización de la participación ciudadana no es más que el accionar estratégicamente orientado a generar una apariencia de intervención sobre el decurso de las problemáticas significativas de la vida en sociedad, sustentado por una oferta -variada y heterogénea- de candidatos políticos que se ofrecen en el espacio público como mercancías, regidos por una lógica mercantil que designa como triunfante a aquel que posee una característica diferencial, un atributo novedoso escasamente vinculado, las más de las veces, del quehacer político. La cultura atravesada por lo espectacular halla en los medios masivos de comunicación aliados estratégicos para ejercer el rol de promotores de estas expresiones aparentes de lo político. Pero ello no es el mero reflejo de una industria mediática mercantilizada; es, ante todo, el corolario de una sociedad que no puede prescindir de la mediación tecnológica instantánea que ofrecen las comunicaciones de masas para garantizar el contacto entre los actores sociales. 
En efecto, para Debord (1967) la consolidación de la sociedad espectacularizada "señala el momento en que la mercancía ha alcanzado la ocupación total de la vida social" (p. 12). El empobrecimiento, el sometimiento y la negación de la vida no son más que tres características que imprime lo espectacular a la totalidad de las relaciones sociales establecidas entre las personas en un mundo en el que la producción económica se erige como soberana al interior de las sociedades y extiende su poderío a escala planetaria.

La mediatización de la política

En su análisis sobre las sociedades contemporáneas, Norbert Lechner (1996) señala el pasaje de "la preeminencia de la palabra, de los grandes relatos y aún de los discursos políticos" a la lógica de la imagen. La cultura de la imagen habría operado sobre la alteración de la idea que los ciudadanos se hacen de la política. En efecto, "cuando el don de la palabra es restringido por el manejo de la imagen, cambian las estructuras comunicativas sobre las que se apoyan tanto las relaciones de representación como las estrategias de negociación y decisión". (p. 6) Por mediatización de la política se entiende no la tarea de mediación entre intereses divergentes conferida desde sus orígenes a los instrumentos de difusión, sino al avasallamiento de la comunicación pública por los mecanismos del mercado y la imposición en su lugar de un modelo comunicacional publicitario.

La mercantilización de las comunicaciones promovió una gradual reducción de los espacios de participación. Ejercer el derecho ciudadano a la intervención en la esfera pública se tradujo -en la práctica- en una mera emisión del voto, generando una ilusión de participación encargada de regular el juego democrático y constreñirlo a los estrechos márgenes de los períodos electorales.

La espectacularización de la política es evidenciable en mayor medida en el campo televisivo, por las propias características audiovisuales de este medio y por el grado de inserción que detenta en los hogares argentinos, sin discriminación de lugar, nivel de ingresos o edad. La televisión comercial se erige, desde la consagración del modelo mercantilizador, como el medio de comunicación por excelencia del tan mentado ciudadano apolítico insostenible por cierto-, consumidor de una multiplicidad de mensajes vaciados de contenido y avisos publicitarios orientados a estimular su decisión de compra.

Ello en detrimento del desarrollo de su capacidad de observar y comprender su propia realidad circundante, advirtiendo los entramados de poder que se tejen por detrás de prácticas asumidas como neutrales, objetivas e inexorables. La televisión "activa emociones que no apuntan a identidades o soluciones políticas viables en los mundos sociales de estos espectadores". (Barnhurst, Cordeiro y Sampedro, 2003, p. 234) La obsesión por la cuantificación constituye otra arista visible del proceso de mediatización de la política. Los números de las encuestas manejan el accionar político como si representasen fielmente la opinión de uno o varios ciudadanos tomados en conjunto. Pero las encuestas - de intención de voto, tendientes a medir el impacto de una medida o de imagen- constituyen meras herramientas orientadas a operacionalizar datos socioculturales dinámicos y variables, encasillándolos en perfiles y clústers diagramados con anterioridad de manera de obtener resultados previsibles dentro de los márgenes esperados. El problema no es la herramienta en sí, sino su aplicación irrestricta a momentos y poblaciones heterogéneas para su posterior homogeneización en una variable porcentual cuya publicación estratégica en contextos mediáticos favorables incide en mayor o menor medida en la toma de partido ante cuestiones de índole ciudadana. La ilusión de participación, bajo la aparente canalización de los deseos y problemáticas de la población por medio de las encuestas, realimenta la 
hegemonía cultural, económica y política de los grupos de poder. En efecto: Los sondeos ofrecen a las elites un conocimiento prospectivo. Les señalan las preferencias ciudadanas que atenderán o ignorarán. Al público, en el mejor de los casos, una encuesta le permite juzgar retrospectivamente a los gobernantes, según sus actividades pasadas o unas promesas cuyos efectos aún no pueden evaluar. Pero un descenso en los barómetros de popularidad no implica la destitución del líder. Éste puede aprender qué retórica desplegar y qué proyectos ocultar. La iniciativa de las elites les confiere ventaja sobre los ciudadanos, que no financian sondeos, ni deciden los temas o las preguntas; sólo contestas. Esta asimetría conlleva el riesgo de la manipulación. (Sampedro, 2000) La demoscopia -el estudio de las opiniones, gustos y comportamientos de la población mediante encuestas- no se consagra como instrumento portador de verdades absolutas sino en el marco de la trasposición de la comunicación política en Marketing político, una nueva disciplina con reglas y procedimientos propios.

Esta mutación resulta de cabal influencia en la mediatización de la política, y se evidencia principalmente en cuatro formas: el reemplazo de la comunicación periodística por la comunicación institucional -de organizaciones y empresas con intereses sectoriales; la prevalencia del dato cuantitativo por sobre el dato cualitativo; la influencia de la imagen por sobre las propuestas políticas; y la extensión de la lógica mediática a las prácticas políticas. Esta última variable tiende a instalar en la esfera pública candidatos políticos siguiendo, en cada caso, una de las siguientes estrategias: posicionándolos como celebrities y explotando su carisma y llegada al público; postulándolos como outsiders de la política, cercanos a la gente -esa entidad amorfa e indefinida- porque viven y padecen el día a día como un ciudadano común; o en función de su capacidad de generar noticiabilidad, repercusión o impacto. La incidencia de estas mutaciones en el espacio político se advierten en la situación crítica que atraviesan los partidos y organizaciones de base. En efecto: "la necesidad de recursos económicos para el ejercicio de la política se ha acrecentado tanto con la importancia de la cultura mediática que impone una fuerte dependencia de los partidos y de los candidatos respecto de los aportes corporativos". (Rouvier, 2004, p. 167) El modelo publicitario de la política triunfa por la convergencia de prácticas de uno y otro campo y el intencional solapamiento de esferas en pos de mostrar el avance del Marketing político sobre el periodismo profesional y la comunicación pública como un proceso de evolución de las disciplinas y de adecuación a las prerrogativas de la nueva era categorizada como sociedad de la información.

Es así como "las estrategias de producción periodística se basan en comunicados, pseudoeventos, y otras facilidades que la comunicación institucional proporciona. (...) en lugar de censura, hay cada vez más medidas proactivas e información procesada por parte de los gobiernos y grupos económicos". (Cicalese y Rinaldi, 2006) Finalmente, la mediatización de la política se advierte en el reemplazo del debate público, territorial, focalizado, por el debate televisivo, dirigido a audiencias masivas, vedando la capacidad de respuesta y gobernado por el minuto a minuto. Esto provoca la asimilación entre opinión pública y opinión publicada por los medios masivos, reduciendo la presencia política a aquellos que pueden acceder a los grandes grupos dominantes y presentar sus propuestas a la ciudadanía/audiencia.

El lenguaje tiene la capacidad de forjar una visión de mundo, interpretar la realidad circundante y traducirla en términos compartidos. El proyecto fundamental del neoliberalismo se propuso reproducir un saber legitimante de una forma de vida adaptada a la configuración mundial, propalando valores ligados a esta organización y promoviendo su encarnación en prácticas sociales ratificadoras de esa posición. 
El proceso de mercantilización de las comunicaciones no constituye un fenómeno de reciente emergencia, sino que sus orígenes se remontan a los años '20 norteamericanos cuando, de la mano de avances tecnológicos significativos, los medios de comunicación comenzaron a ejercer un importante rol en el proyecto de expansión de la american way of life. Sin embargo, es en la década del '90, con la caída efectiva del bloque socialista y la consolidación de su poderío como única potencia hegemónica mundial, cuando Estados Unidos consagra su propósito imperialista propalando una visión de mundo con tendencias universalizantes orientada hacia la exportación y adopción de sus formas de vida, costumbres y hábitos sociales.

Con la superación de las trabas políticas vehiculizada por la sucesión de gobiernos dictatoriales y la instauración de las políticas librecambistas a nivel planetario, Estados Unidos inició su tarea de aculturación de las sociedades latinoamericanas vía inserción de las tecnologías de la comunicación y la información, responsables en gran medida del intento de adopción del estilo de vida norteamericano.

Las innovaciones tecnológicas en el campo de la comunicación como formas cristalizadas del poder de los medios en la nueva etapa del capitalismo mundial, introducen "modalidades de comunicación que (...) fueron posibles sólo en la medida en que la tecnología materializó cambios que desde la vida social daban sentido a nuevas relaciones y nuevos usos". (Martín Barbero, 2010, p. 160) Analizar los cambios culturales provocados por la instauración de un sistema comunicacional global implica superar las posturas mecanicistas sostenidas en el modelo emisiónrecepción para advertir las mediaciones, los usos sociales y las prácticas derivadas de esas formas de apropiación de los medios masivos por parte de la ciudadanía, proponiendo incluso formas alternativos de participación en el espacio público.

La existencia de un modelo hegemónico de comunicación no implica ni su total dominación de la totalidad de las prácticas, ni la adopción pasiva de los mandatos extranjeros al interior de cada Estado. La hegemonía no constituye más que un proceso activo de articulación de significados, definiciones, prácticas sociales y valores de un grupo social que es incorporado, mediante procesos de socialización diversos y variables en función de los condicionantes históricos de cada lugar, en forma de verdades inexorables y excluyentes de posibilidades alternativas.

Los medios de comunicación -tanto o más que la institución escolar, la institución familiar y la institución religiosa- reproducen el saber hegemónico, contribuyendo -directa o indirectamente, consciente o inconscientemente- a la consolidación del modelo de ciudadano afín a los intereses económicos y políticos de cada fase histórica.

En efecto; una de las consecuencias de la modernización tecnológica, de la complejización sociocultural y de la instrumentalización de internacionalización de la política es un mayor desplazamiento del poder político hacia los medios de comunicación social. (...) el espacio público, la televisión y otros medios de información tienden a reemplazar el papel mediador de los partidos y el parlamento. (Calderón y Szmukler, 2006, p. 228) La mediación gobierno-ciudadanía que ejercen los dispositivos comunicacionales en lugar de los actores políticos los convierte en elementos estratégicos de dominación. Es en el marco de las prácticas tendientes a reforzar el status quo que se advierte esta connivencia del proyecto empresarial/mediático con el deseo de conservación y fortalecimiento de las formas hegemónicas de ejercicio del poder que tienden, por las necesidades del sistema capitalista propias del período analizado, a despolitizar a la ciudadanía y reducir los canales de participación. 
El auge de las nuevas tecnologías de la información y la comunicación a nivel masivo comenzaba a vislumbrarse por estas latitudes ya en la década del '90, cuando la proliferación de los medios y canales alternativos tornó imperiosa la inserción de la sociedad argentina en la nueva era de la mediatización digital. La apertura a nuevas formas de comunicación y la consolidación de un paradigma sustentado en la desaparición de un emisor unilateral y la aparente democratización de los medios, impulsó la ilusión de una mayor democratización de la vida cotidiana, y especialmente de las posibilidades de acceder a una mayor participación política.

La concepción de una esfera público-política virtual afianzada en el ciberespacio, en la que todos los ciudadanos fueran capaces de informarse por sus propios medios y adquirir un rol protagónico en la toma de decisiones, acompañó el proceso de consolidación de las nuevas tecnologías propiciando el fortalecimiento del Marketing político en su reconversión digital. Esta idea de una ciberdemocracia se basaba en el acceso ilimitado "al conocimiento, debate y toma de decisiones" (Sampedro, 2000, p. 9). La participación política se convertiría, a la luz de esta utópica esfera virtual, en una posibilidad de intervención irrestricta sobre los fenómenos cotidianos desde la comodidad del hogar, al alcance de quienes pudiesen acceder a la red global que, se asumía, sufriría una expansión tal que alcanzaría a la totalidad de la población a un bajo costo.

La gran metáfora de la democracia trocada en virtualidad y participación mediatizada resultó ser el modelo lógico para la mercantilización de las comunicaciones políticas. La reducción -y, en algunos casos, anulación de las distancias y los tiempos-, la desaparición de las jerarquías, la recuperación de la comunicación dialógica y la transformación de lo privado en público, constituyeron las premisas fundamentales sobre las que se erigió la utopía de la ciberdemocracia. (Sfez, 1999) La reducción espacio-temporal es un hecho innegable si se analiza a la luz de las herramientas tecnológicas que hacen posible la comunicación instantánea a nivel planetario, promoviendo nuevas formas de socialización y preservación de lazos sociales a pesar de la distancia física. Los medios tradicionales adoptan esta configuración e incorporan canales de retroalimentación, convirtiéndose en usinas de debate sobre los acontecimientos polí- ticos, sociales y culturales que atraviesan la cotidianeidad de los ciudadanos.

La distancia espacio temporal entre representantes y representados es superada gracias a la instauración de una esfera pública virtual, propiciando el surgimiento de nuevas vías de canalización de las preocupaciones ciudadanas, de rápido acceso y fácil utilización. Sin embargo, el contacto establecido con autoridades políticas, instituciones públicas o responsables mediáticos no deja de ser virtual, es decir, ficticio.

La proliferación de medios, soportes y canales de comunicación, más que convertir al ciudadano en un ciberactivista, alimentó su pasividad bajo una aparente potencialidad participativa, dotándolo de múltiples instrumentos de información y respuesta que no necesariamente inciden -y en la práctica se constata su ineficacia- en las decisiones políticas. Por su parte, la desaparición de las jerarquías vendría a proponer la gestación de nuevas formas de gobierno y participación política que posibilitarían la multiplicidad de visiones y la "interconexión descentralizada, abierta a infinitos actores y campos". Una verdadera democracia, entendida como gobierno del pueblo, se haría posible gracias a los avances tecnológicos en materia de comunicación, estableciendo un poder horizontal ejercido por todos aquellos ciudadanos que se mantuviesen informados y 
participaran de los debates públicos virtuales, foros y referéndums interactivos que las autoridades pusieran a su alcance.

Así como la reducción de la distancia resultó ser ficticia, este modelo de ciberdemocracia horizontal que se intentó instaurar, no hacía más que reproducir la lógica de funcionamiento de los medios de comunicación; el incremento de la oferta informativa no implica necesariamente un proporcional aumento de la calidad de esas informaciones, así como la apertura de nuevas vías de respuesta -en reemplazo de las tradicionales cartas de lectores o mensajes de las audiencias- no implica necesariamente algún grado de incidencia sobre las decisiones del medio.

La lógica selectiva -en función de limitaciones sociales, culturales o económicas- siguió siendo un condicionante insondable para el acceso a las informaciones de la ciudadanía considerada en su totalidad. La información, y más aún aquella que resulta determinante para la definición del rumbo de la sociedad en su conjunto, permanecía y permanece -aún en el mundo feliz de la ciberdemocracia- en sectores reducidos y, por ende, ajena a las mayorías.

La tercera premisa propuesta por Sfez (1999) pregona la recuperación del diálogo entre los ciudadanos y entre éstos y las autoridades gubernamentales, empresariales o sociales. La visibilidad e instantaneidad de las redes sociales dispuestas a voluntad y arbitrio de los usuarios, permitiría superar la individualidad y restablecer la conversación como forma de vinculación social tendiente al logro de beneficios recíprocos.

Sin embargo, en la práctica, la interrelación dialógica no parece ser el fin por el cual los sujetos acceden a las plataformas y redes sociales. Lo que se advierte es un intento de demostración del punto de vista propio, rechazando e incluso injuriando a quienes no poseen el mismo enfoque.

El uso de las nuevas tecnologías de la información y la comunicación, más que impulsar el diálogo, son utilizadas como campos de fuerza en los que se ejerce una lucha por imponer la visión unipersonal y unilateral sobre un suceso particular, el futuro del país o la imagen del político de turno o la celebrity de moda. Ello sin mencionar que -como afirma Beniger (1987)- toda nueva forma de comunicación termina siendo canalizada en pos de la satisfacción de unos intereses institucionales sectorizados.

Finalmente, los defensores de la ciberdemocracia afirmaron que las nuevas tecnologías permitirían convertir lo privado en público, expandiendo la esfera pública y generando nuevas prácticas de socialización. Efectivamente, las fronteras entre lo público y lo privado se diluyeron como consecuencia de la aparición de redes sociales de carácter biográficas en las que es posible hallar la historia de vida del usuario, conocer sus amistades, preferencias y obligaciones, e incluso interactuar con él aún sin conocerlo personalmente.

Aún si se sostiene esta afirmación, poseer una elevada cantidad de contactos, interacciones, posteos o likes no supone el incremento de la calidad de las interrelaciones virtuales, sino sólo un aumento en términos cuantitativos. En efecto, "hablando con todo el mundo lo particular sólo se convierte en general (alcanza a más gente). Una cosa bien distinta es que lo que se diga resulte universal (relevante y representativo de todos)". (Sampedro, 2000) Que un político reciba abundantes visitas a su sitio oficial no implica que sus propuestas de campaña sean aceptadas por los votantes, o siquiera que su plataforma -virtual- sea gráfica y visualmente 
atractiva. Una multiplicidad de factores pueden llevar a un usuario a visitar un sitio o juzgar aceptable o no una publicación.

Universalidad, relevancia y representatividad constituyen pilares básicos de la comunicación política entendida como el ejercicio permanente de brindar información a la ciudadanía para que desarrolle una capacidad de reflexión y crítica, y construya una perspectiva propia que le permita inteligir los acontecimientos de su entorno. La utopía de una ciberdemocracia resulta insostenible por su propia incapacidad de alcanzar a todos los ciudadanos de un país, en función de condicionamientos sociales, económicos y culturales que restringen la posesión de una computadora, el acceso a Internet, el consumo desigual de la red -por sexo, edad o nivel socioeconómico-y la propia habilidad para manejar plataformas interactivas.

Pero además resulta inadmisible en esta sociedad del espectáculo que torna real lo ficticio y otorga una primacía ontológica a las formas aparentes de la participación política cristalizadas en las mediciones de aprobación o rechazo, la multiplicación de canales y medios de intervención ciudadana que distancian en lugar de acercar a los distintos actores sociales, y la proliferación de candidatos políticos dotados de un riguroso conocimiento de las reglas dominantes del campo político; a mayor desarrollo de una imagen pública eficaz, mayor será la aceptación del electorado, aún cuando ello implique el abandono efectivo de la política.

Continuidades y rupturas: persistencias del imaginario neoliberal y nuevas formas de ciudadanía mediática

El análisis de las mediaciones que generan un cambio significativo en la transformación del sentido de la vida de las comunidades implica la introducción de variables que permitan pensar no solamente las rupturas generadas con un modelo u orden previo, sino también las continuidades que, solapadamente, subsisten en el imaginario social y generan formas de participación política y partidaria consecuentes con la ideología neoliberal. En todas las formaciones culturales pueden diferenciarse tres estratos: lo arcaico, lo residual y lo emergente, expresiones del carácter dinámico y cambiante de las representaciones imaginarias y las prácticas sociales resultantes.

Lo arcaico se vincula con aquellas percepciones, imaginarios y representaciones propias de un pasado que se recupera únicamente en términos de su rememoración, pero no ejerce una influencia perceptible en las formaciones culturales presentes.

Lo residual, en cambio, constituye aquello que, a pesar de constatarse su emergencia en un tiempo pasado, continúa ejerciendo un poder de influencia significativo sobre los imaginarios actuales. En esta categoría se incluyen dos tipos de elementos, tanto "Ios que ya han sido plenamente incorporados a la cultura dominante o recuperados por ella, y los que constituyen una reserva de oposición, de impugnación a lo dominante". (Williams, 2009) Y lo emergente representa la innovación de los sentidos, los significados y las prácticas, aquellos procesos culturales que provocan un quiebre sustancial en el desarrollo de la vida de la comunidad, un cambio en el sentido de las prácticas y los saberes dominantes.

Interesa, a los fines de este estudio, advertir que un cambio estructural, un giro en las proyecciones políticas o económicas de un país no representa el abandono definitivo de los saberes y prácticas a ellos vinculadas.

Lo que hace más resistencia a las transformaciones de superficie (...) son las mentalidades, la trama de valores, prácticas, imaginarios culturales y religiosos, prejuicios, tradiciones, que conforman el tejido de la vida social. Es 
más fácil que se quiebren las estructuras económicas o las formas de dominación política que esa subterránea continuidad de los lenguajes de la cotidianeidad que sustentan la visión del mundo de una comunidad. (Forster, 2012) En efecto, en la Argentina del siglo XXI puede evidenciarse la persistencia del imaginario neoliberal en enclaves concretos y núcleos de poder hegemónicos a nivel regional, aunque dotados de un poder decisivo sobre una importante porción de la ciudadanía.

De lo anteriormente expuesto se comprende que no se intenta sostener aquí el reemplazo de un modelo de sociedad por otro, en tanto ello implicaría no sólo un aislamiento total de la región de los imperativos propios de la producción capitalista mundializada, sino que además estaría sustentando una visión mecanicista de cambio social cuyas limitaciones ya han sido explicitadas por un cuantioso caudal de reconocidos teóricos sociales.

No obstante esto, la gestión de gobierno de determinadas facciones políticas contemporáneas permite advertir con mayor claridad la implementación y el seguimiento de las premisas impuestas por el Consenso de Washington, no sólo en un nivel discursivo, sino también pragmático, a la luz de la derogación y aprobación de disposiciones normativas.

La filosofía PRO y las formas residuales de la comunicación mercantilizada

Una de las herramientas de mayor utilidad a los efectos de develar los pilares rectores de una gestión -el mito de gobierno que orienta su ejercicio del poder- es el análisis del discurso. La comunicación gubernamental, en su actuación cotidiana, transfiere la ideología subyacente a cada decisión, argumentación u opinión que los actores políticos reproducen en el escenario público/mediático.

Retomando una de las formas de inserción en el sistema mediático siguiendo su propia lógica, puede advertirse que la estrategia seleccionada por los jefes de campaña de Mauricio Macri en 2007 para su posicionamiento como candidato, apuntó a lograr su aparente diferenciación -en base a su rol de empresario- de los políticos "corruptos", "deshonestos" o "demasiado politizados", tal como el jefe de gobierno suele caracterizar a la generalidad del espectro político opositor. Posicionándose como un outsider de la política, Macri basó su candidatura en propuestas de igualdad e inclusión que no lograron superar los límites discursivos. Aspirando conquistar la integración y unidad de los porteños y la disipación de los conflictos, su discurso tiende a conformar un nosotros que dista de incluir a los sectores vulnerables y las poblaciones migrantes de los países vecinos.

Al crear otro ante el cual contrastarse para reivindicar un nacionalismo desmedido y criminalizarlo con la colaboración de los grupos oligopólicos de comunicación, la gestión PRO construyó un discurso segregacionista y xenófobo que contribuyó a la reducción de los canales de participación de cuantiosos sectores.

Esta construcción ideológico-discursiva puede leerse a la luz de la distinción entre Pueblo con mayúscula, el sujeto político de hecho, y el pueblo con minúscula, "la multiplicidad de los cuerpos necesitados. Los discursos diseminados por la esfera mediática afines al proyecto capitalino distinguen un nosotros agredido por un otro atacante; entre un Pueblo con existencia política, derechos y necesidades, y la vida desnuda, "la clase que, no de derecho sino de hecho, está excluida de la política. (Castro, 2008, p. 61) En términos foucaultianos, efectúa una escisión entre la vida protegida por el gobernante, la vida digna de ser vivida, de aquella que no representa un valor sustancial para el desarrollo de la ciudadanía. Una práctica efectiva de biopoder, el poder de decisión 
del gobernante sobre la vida misma del ciudadano. En efecto, "vida y muerte no son propiamente conceptos científicos, sino conceptos políticos que, en cuanto tales, adquieren un significado preciso sólo a través de una decisión" (Castro, 2008, p. 62). Una decisión que se dirime entre hacer vivir o dejar morir, decretada desde el ejercicio de una política segregacionista y excluyente del espacio público.

El discurso macrista propugnó un uso irrestricto de la esfera pública por aquellos que se erigían en ciudadanos consumidores plenos. La utilización de la esfera pública como una esfera privada a la que tienen acceso sólo quienes detentan un poderío económico sustancial, fortalece el avance del ciudadano consumidor por sobre el ciudadano comprometido con el cambio social.

Durante la primera intendencia del actual jefe de gobierno porteño se dio inicio, por decreto del Poder Ejecutivo nacional, al proceso de promulgación de una medida legislativa tendiente a regular el ejercicio mediático, reduciendo la concentración del sistema nacional y promoviendo la generación de contenidos culturales nacionales y latinoamericanos. La Ley de Servicios de Comunicación Audiovisual ( $\left.N^{\circ} 26.522\right)$ fue aprobada por el Senado y la Cámara de Diputados en octubre de 2009, luego de más de veinte años de lucha de organizaciones sociales y colectivos de expertos en comunicación y cultura que pugnaban por la derogación de las cláusulas privatizadoras adoptadas durante el gobierno menemista y la superación de la legislación reglamentada por el régimen dictatorial para incrementar su poder.

Sin embargo, las formas de apropiación del espacio público impulsadas por el gobierno de Mauricio Macri, junto con la reducción de las vías de canalización de las necesidades ciudadanas y la denegación de los conflictos como ejes sustanciales de la práctica política, permiten advertir una continuidad de formas residuales de comunicación que pregonan la persistencia del ciudadano-consumidor.

El uso irrestricto de los medios de comunicación afines a su ideología como meros instrumentos de difusión de las actividades gubernamentales, el ocultamiento por parte de estos grupos oligopólicos de procesos penales a los que es sometido el jefe de gobierno y sus propios funcionarios, son reflejo no sólo de la mancomunación de intereses entre los grupos económicos y los representantes del gobierno, sino también de un uso privado, político y partidario del elemento público.

\section{El ciudadano PRO}

En el desarrollo de este escrito el concepto de ciudadanía ocupa un lugar central. Es por ello que resulta necesario esclarecer qué se entiende por ciudadanía para advertir las diversas acepciones que cada gobierno emplea en la comunicación de sus actividades, así como en la generación de políticas públicas orientadas al modelo de ciudadano que respalda su proyecto.

La acepción liberal define a la ciudadanía como una suerte de contrato entre los individuos y el Estado mediante el cual los primeros contribuyen con prestaciones para acceder al usufructo de un conjunto de servicios públicos brindados por el aparato gubernamental. La acepción social, en cambio, "ve a la ciudadanía como una pertenencia comunitaria o social a través de la cual el individuo se va autodesarrollando y autodeterminando". (Calderón y Szmukler, 2006, p. 231) En este sentido, el individuo no es, como en la acepción liberal clásica, un individuo externo al Estado, sino un participante activo del espacio público que ejerce su intervención mediante 
los mecanismos políticos dispuestos para tal fin -organizaciones barriales, partidos políticos, comisiones de fomento-.

El estudio de las formas de cimentación de modelos de ciudadanía constituye un elemento indispensable para develar la ideología que nutre la práctica gubernativa. Es por ello que resulta necesario analizar los modos construcción del discurso político de Mauricio Macri, haciendo especial hincapié en la observación de acontecimientos significativos de su primera gestión que permiten develar su intención de imponer un modelo de ciudadano afín al sistema económico-político neoliberal, categóricamente excluyente y presumidamente apolítico.

El análisis del discurso de cualquier representante del poder político, mediático o econó- mico, en tanto análisis del uso cotidiano del lenguaje, torna manifiestas las significaciones e imaginarios que circulan en la sociedad mediante un proceso de producción y reproducción de sentidos y simbologías colectivas. En efecto, esta perspectiva conlleva siempre una crítica tendiente a "desnaturalizar el sentido y la significación de los intercambios lingüísticos". (Raiter y Zullo, 2008, p. 29) Cabe destacar que el análisis crítico del discurso no es sólo una herramienta para desentra- ñar la conformación de las producciones lingüísticas, sino una corriente de investigación; una perspectiva -crítica- de hacer investigación (...). Focaliza en problemas sociales y especialmente en el rol del discurso en la producción y reproducción de abuso de poder o dominación. Siempre que sea posible, lo hace desde una perspectiva que sea consistente con los mejores intereses de los grupos dominados. (van Dijk, 2001, p. 96) Tal como ha sido analizado anteriormente, la doctrina neoliberal puede caracterizarse por tres rasgos centrales: la reducción de la intervención estatal en materia social y cultural, la privatización de las otrora instituciones públicas -o el incremento de capitales privados en la administración pública-, y la consolidación de una perspectiva individualista que opera en el conjunto social como eje rector de la discriminación y la exclusión.

El análisis crítico del discurso deberá centrarse, en consecuencia, sobre estos tres rasgos, mediante la exploración de los discursos gubernamentales empleados en cada ocasión para desentrañar.

\section{Políticas educativas}

Los dos primeros rasgos del modelo neoliberal reflejan una intencionalidad privatista tendiente a reducir la intervención del Estado en dos áreas sustanciales: la educación y la cultura. Durante los primeros años de la llamada década menemista se gestó una de las reformas más radicales en materia educativa. A través de la promulgación de la Ley Federal de Educación, cuyos postulados asumían la necesidad de construir una nueva institución escolar capaz de formar mano de obra capitalizable, se inició un proceso de descentralización que culminó en un vaciamiento de la educación pública.

Las reformas educativas neoliberales no sólo provocaron la reducción de la oferta académica a vastos sectores, negándoles la posibilidad -otrora garantizada por el Estado- de acceder a una educación pública, gratuita y laica. La privatización de la gestión educativa condujo, asimismo, a la eliminación del rol de la escuela como promotora de cambios sociales. La ciudad de Buenos Aires constituye uno de los núcleos centrales en los que el impacto de esta reforma generó mayores perjuicios, delegando la responsabilidad por la educación pública a un puñado de inversores y empresarios allegados a la cúpula gubernamental. 
La pauperización de la educación pública, el deterioro del salario y la ocupación docente y la masiva expulsión de jóvenes y adultos de las instituciones escolares, se intensificaron durante la crisis argentina de 2001, tras la cual los docentes porteños -y de todo el país- pudieron asistir a un período de mayor estabilidad.

Si bien el discurso dominante de la privatización se impuso durante la década del ‘90, la administración macrista promovió la consolidación de la racionalidad mercantil en esferas sustanciales del ejercicio ciudadano, entre las que se incluye la educación civil. El conflicto con los docentes porteños se inició durante el transcurso de los primeros meses de gestión de Mauricio Macri, en julio de 2008, tras el intento de instalar una carpa frente al Gobierno porteño en reclamo de mejoras salariales y reacondicionamiento edilicio para los colegios de la ciudad, en el que algunos docentes resultaron lesionados. Como consecuencia de este incidente, y haciendo explícita su intencionalidad de premiar a los docentes que no se manifestaban, rechazando su adhesión al paro convocado por las autoridades gremiales para las sucesivas jornadas, y agravando el conflicto con los sectores mayoritarios que reivindicaron su derecho a efectuar reclamos en el espacio público, Mauricio Macri sostuvo en conferencia de prensa que: Estamos proponiendo cambios y se ve que hay gente que no quiere llevar adelante los cambios. Hoy, lo que vimos hoy me llena de tristeza, lo que reflejaron las cámaras de televisión forzando episodios a partir de una carpa absurda para justificar después volverle a robar un día de clase a los chicos, y ya no sólo de acá, sino de todo el país. (...) Todos tenemos que convivir. Aquellos que reclaman con aquellos que también transcurren el día en otras actividades.

A partir de este primer conflicto, el congelamiento salarial de los docentes porteños, la aplicación de una política de premios y castigos a los profesores y funcionarios que se adecuaban o rechazaban el rumbo neoliberal de la política educativa, y la merma del presupuesto destinado a educación para el siguiente año, provocaron el recrudecimiento de la lucha de los gremios docentes y la cristalización de un enfrentamiento entre un modelo privatizador que asignaba mayores partidas a instituciones de gestión privada y los defensores de la educación pública y gratuita.

Durante los primeros meses de 2009, y ante la reducción de la partida presupuestaria asignada a la educación pública de la ciudad y el congelamiento de los salarios, los docentes porteños decidieron emprender una nueva etapa en la lucha por la defensa de la educación pública, llamando a los docentes a adherirse a dos jornadas de paro en mayo del mismo año. Como consecuencia del alto acatamiento que esta medida de fuerza logró entre los trabajadores de la educación, el gobierno porteño decidió descontar a los docentes los días no trabajados aduciendo un supuesto compromiso con los trabajadores buenos de la ciudad que merecen cobrar. Frente a la insistencia de un grupo de periodistas por conocer los motivos que generaron la aplicación de este descuento frente al aumento del salario de los funcionarios de la legislatura- el intendente manifestó su posición.

El que no trabaja, no puede cobrar por no trabajar. Nosotros hemos dicho que no es lo mismo trabajar que no trabajar y vamos a trabajar muchísimo durante todo este año en darle el lugar que corresponde al buen recurso humano que tiene la ciudad (...). Esos este gobierno los va a premiar, a los que no quieren trabajar este gobierno los va a ir separando cada vez más, porque esto no puede seguir así. Nosotros hemos heredado un gobierno en el cual no sólo las veredas están rotas, no sólo las plazas están rotas, sino que hay mucha gente que se cree que tiene derecho a cobrar un sueldo por no hacer nada, eso se tiene que acabar (...). Los sistemas están hechos justamente para amparar a los vagos que no quieren ir a trabajar. (C5N, 2009) El conflicto entre los docentes porteños y el intendente de la ciudad, lejos de hallar una vía de resolución que pudiera garantizar el normal funcionamiento de las instituciones educativas estatales, continuó radicalizándose incluso hasta los 
últimos días de su primer mandato. En efecto, en los últimos meses de 2011 el gobierno porteño, habiendo logrado garantizar su continuidad en el poder por un período más, envió a la legislatura local un proyecto de reforma de las Juntas de Clasificación docente, modificando cabalmente el estatuto.

El proyecto, elaborado por el ministro de Educación del PRO, Esteban Bullrich, proponía modificar el sistema vigente de selección del personal docente por medio de concursos públicos en los que se organizan las inscripciones, los puntajes, las designaciones y las inscripciones a través del debate en diversas juntas, reemplazándolo por un Sistema Único de Clasificación Docente que dependa sólo del Ministerio de Educación. (Asamblea Docente del Distrito Escolar N8, 2011).

El intento de implementación de una regulación de esta naturaleza -rechazada en la legislatura y sustituida por una normativa que respeta la diversidad y pluralidad de la composición de las juntas- refleja no sólo una voluntad de control absoluto sobre la calificación y designación de los cargos docentes, sino fundamentalmente un explícito intento de manejar el conflicto ejerciendo una intervención profunda sobre sus pilares básicos. Implica, asimismo, un intento de reducir las posibilidades de lucha de los docentes y tornar inapelable la defensa de la educación privada ante la irresponsabilidad de los profesionales públicos.

\section{Políticas securiticias}

La cristalización de este discurso privatizador se torna más evidente aún en materia de políticas de lucha contra la inseguridad, fenómeno que ha suscitado un crecimiento significativo en los últimos años. Como se expuso anteriormente, la proliferación de un discurso basado en la dicotomía ellos/nosotros opera en el conjunto social como un eje divisorio entre los vecinos -el ciudadano PRO-y los otros "indeseables" -adquieran éstos la figura del trapito, el cartonero, el motochorro o el migrante latino.

La consolidación de esta perspectiva individualista en los ciudadanos capitalinos actúa como generador de actos xenófobos y discriminatorios, depositando en la figura del diferente todos los miedos sociales cuya responsabilidad el intendente les atribuye. Los sucesos ocurridos en el Parque Indoamericano como consecuencia de la ocupación del predio por parte de diversas comunidades en reclamo de mejoras en su calidad ocupacional durante los últimos días del año 2010 estimularon la emergencia de discursos explícitamente xenófobos que resultan especialmente útiles para constatar la existencia de una gestión aferrada en el deseo de eliminar a la población indeseable -o disciplinarla en caso de no lograr su cometido-.

La antinomia deseable-indeseable se refleja en la sistemática denostación de los inmigrantes de países limítrofes, provenientes sobre todo de Bolivia y Paraguay, que han arribado a la capital argentina en busca de mejores condiciones de vida que las que su país de origen pudo ofrecerles. Estas comunidades, acompañadas de habitantes de las villas colindantes al parque, se hicieron presentes en el Indoamericano para denunciar la arbitraria ausencia gubernamental que en materia de vivienda y educación ejerce el gobierno porteño contra las poblaciones marginales.

Una de las cuestiones que mayor repercusión obtuvo en la discusión en torno de la ocupación del predio, fue la nacionalidad de las familias adherentes al reclamo. La naturalización de la pobreza y, consiguientemente, de la delincuencia como consecuencias del devenir histórico, sumados al mito del inmigrante marginado que amenaza 
con ocupar fuentes de empleo nacionales, convergen en una misma configuración imaginaria que deriva en la segregación del extranjero no europeo y de todo aquel que ocupe los escalones más bajos de la pirámide social.

Dicha construcción, producto de una descontextualización intencional, oculta que la tasa de inmigrantes de países latinoamericanos que residen en la Argentina -y se instalan en la ciudad capital-, se mantiene en un promedio que no alcanza el $3 \%$, ocupando empleos que, en su gran mayoría, se insertan dentro de la categoría de informal o subempleo.

En efecto: En los últimos años la relación entre "nosotros" -el propio grupo-y "los otros" -los diferentes- se representa como una relación antagónica entre opuestos. Esta oposición toma forma al percibirse las relaciones entres estos diferentes sectores como signadas por la "competencia"; en este caso "los otros" aparecen disputando empleos, viviendas, servicios públicos, etc. (...). Pero también este antagonismo toma cuerpo a partir de la idea de "peligrosidad social". En este caso "los otros" quedan asociados indefectiblemente a diversas imágenes con cargas valorativas negativas: ilegalidad, inmoralidad, invasión, delincuencia, usurpación, amenaza y atraso. (Chiriguini y Gravano, 2008, p. 353) Estas formas de racismo social que describen los autores constituyen fuentes de inconmensurable utilidad para la legitimación del orden instituido y la consolidación del poder gubernamental de quien apela a justificaciones de este tipo para fortalecer representaciones negativas en torno a los sectores oprimidos, desestimar su lucha y evitar cuestionamientos a su autoridad. Éste es, en efecto, uno de los pilares rectores de la política macrista. En una conferencia de prensa brindada a los medios para responder ante los primeros decesos ocurridos durante el intento de desalojo del parque, Mauricio Macri omitió su responsabilidad en el conflicto y se indignó al ser interrogado por la subejecución que efectuó de la porción del presupuesto consignado a la construcción de viviendas con fines de asistencia social. "Parecería que la Ciudad de Buenos Aires se tiene que hacer cargo de los problemas habitacionales de los países limítrofes", afirmó el jefe de gobierno. (TELAM, 2010). En sucesivas intervenciones mediáticas el dirigente se refirió a los ocupantes como "invasores extranjeros" que habrían arribado al país como resultado del "avance de los narcotraficantes y el avance de la delincuencia". Su distinción entre buenos y malos se hizo presente una vez más, distinguiendo entre los vecinos de los barrios aledaños y los ocupas, delincuentes vinculados a una mafia.

Lo anteriormente expuesto se evidencia con mayor claridad cuando el jefe de gobierno hace un llamamiento a los ocupantes del predio: Por eso les pido una vez más a los trabajadores honestos de villas aledañas que se han ido sumando a esas organizaciones delictivas que tomaron este parque que vuelvan a sus barrios, que se diferencien de gente que no cree en el esfuerzo del trabajo, que no cree que (...) en el tiempo se consigue derrotar los problemas de exclusión y pobreza. (C5N, 2010) Al crear un otro ante el cual contrastarse para reivindicar un civismo desmedido y criminalizar la protesta de un sector social profundamente marginal, la gestión PRO construyó un discurso racista y xenófobo que contribuyó a la naturalización de la pobreza, alimentando asimismo el mito de las redes de delincuencia y narcotráfico en torno a los migrantes latinos. La construcción de este antagonismo social confirió a la doctrina del individualismo y la segregación de los ya excluidos un discurso legitimador de una ideología fervientemente neoliberal.

La reducción de la intervención estatal en materia social y cultural, si bien se torna evidente en el análisis de las formas discursivas que la gestión macrista empleó para referirse al conflicto desatado por las condiciones de desinversión y desidia en la que se encontraban las instituciones educativas de gestión estatal, puede evidenciarse con mayor rigurosidad en las políticas públicas implementadas en materia cultural. 
A partir de la sanción de la Ley N2ㄴ.522 de Servicios de Comunicación Audiovisual, múltiples espacios audiovisuales comenzaron a desplegarse para permitir el acceso a las comunicaciones a vastos sectores y el derecho a escuchar y ser escuchados. No obstante ello, la primera intendencia macrista impulsó políticas públicas tendientes a la consolidación de prácticas comunicativas propulsoras de valores segregacionistas y elitistas.

La valoración de las instituciones privadas como política de Estado y la desinversión en áreas públicas sustanciales como el ámbito educativo y el campo cultural, exhiben un marcado alineamiento de su forma de proceder política y los ejes rectores del neoliberalismo. El alquiler de centros culturales reconocidos a empresarios por enormes sumas de dinero para realizar emprendimientos y celebraciones propias, el desalojo de centros culturales y sociales, la clausura o cierre definitivo de centros de gestión populares, la persecución de activistas sociales por parte de la Unidad de Control de los Espacios Públicos, el cierre de actividades culturales gratuitas y el cese de pago a talleristas, artistas y técnicos de los teatros más reconocidos de la ciudad, constituyen algunos ejemplos de esta continuidad ideológica. Algunas medidas más sutiles incluyen la desinversión en centros culturales y el gradual abandono de museos y teatros públicos que no generan grandes sumas redituables de dinero que las conviertan en merecedoras de la inversión pública. Un análisis de las políticas públicas implementadas durante la primera intendencia macrista incluye, entre sus principales medidas de gobierno, "la cesantía de más de 2.000 puestos de trabajo de agentes de salud, educación y cultura (...), un aumento impositivo muy significativo y la reducción del presupuesto educativo", motivando desde el año 2008 una profunda conflictividad con los sectores involucrados. (Raggio y Sabarots, 2010, p. 13).

Si bien este estudio se focalizó en aquellas políticas públicas cuyos destinatarios principales son los jóvenes en situación de vulnerabilidad social, permite dar cuenta de un ejercicio gubernamental tendiente a la exclusión de diversos colectivos en función de su potencial capacidad de generar hechos delictivos.

En efecto, tanto programática como discursivamente se advierte una concepción de los sectores vulnerables como desprovistos de herramientas de socialización y, por ello, imposibilitados de orientarse política y culturalmente en el seno de la sociedad.

En este marco ideológico se analiza la problemática social de los sectores vulnerables desde un imaginario de peligrosidad que se cristaliza en las disposiciones normativas y en las medidas diseñadas para contrarrestar esta situación, así como en las expresiones formuladas para referirse a estas poblaciones. La resistencia por parte de estos sectores a las medidas introducidas, así como el rechazo -total o parcial- de la orientación del gobierno macrista en torno a las políticas públicas culturales, alimenta el imaginario creado en torno a su peligrosidad.

Lo anteriormente expuesto se visualiza con mayor claridad a la luz del análisis del Plan Nacional de Prevención del Delito que, habiendo sido impulsado en el año 2000 y dejado sin efecto en 2008, fue modificado por la gestión de Mauricio Macri, quien decidió su continuidad, así como algunas localidades del Gran Buenos Aires, aunque trastocando sus propósitos originarios. 
A pesar de lo que su nombre permitiría suponer, se trató desde un principio de proveer ayuda a los sectores en situación de vulnerabilidad social -especialmente tras la crisis de principio de siglo-, mediante un trabajo de tipo comunitario orientado a lograr su inserción laboral, cultural, política y social. Pero el cambio de orientación política suscitado en la gobernación local desde la asunción del macrismo, en línea con la transferencia de recursos de las áreas culturales y educativas a las de seguridad y justicia, introdujo profundas modificaciones al plan.

Principalmente este cambio de orientación se tradujo en la modificación de la concepción de los sectores a los que estaba destinado el plan, visualizándolos ya no como grupos marginados de la sociedad cuyos derechos debían ser restituidos, sino como principales responsables de su situación, fomentando una visión estigmatizante y discriminatoria, profundizando las diferencias y provocando mayor fragmentación social.

Los autores del mencionado estudio argumentan, en este sentido, que: El cambio de gestión en el Gobierno de la Ciudad comenzó a hacer sentir sus efectos negativos en relación con las acciones de política cultural dirigidas al conjunto de la ciudadanía en general y a los sectores más vulnerables en particular. Se han mantenido y promovido aquellas que están relacionadas a grandes eventos y recitales, consideradas claves para atraer al turismo. (Raggio y Sabarots, 2010, p. 26) En línea con los argumentos sostenidos en apartados previos, se advierte en este intento de ocultar las iniciativas populares -talleres, centros culturales, bachilleratos populares, murgas, orquestas juveniles- y reducir la participación del Estado en dichos emprendimientos mediante la desinversión sistemática y la implementación de clausuras permanentes, una práctica estratégicamente orientada a la exclusión de lo diferente, expresado aquí por las expresiones populares de raigambre barrial.

Estas prácticas alternativas, reflejo de una contracultura que permanece y resiste a los diversos matices ideológicos de los gobiernos de turno, constituyen alternativas de cambio ante las formas hegemónicas y consagradas de pensar lo cultural y, por ende, lo social como una esfera de la que sólo puede formar parte un grupo selecto de ciudadanos ilustrados. Su capacidad de resistencia supera la mera confrontación para constituirse en prácticas susceptibles de poner en funcionamiento mecanismos de transformación indispensables para garantizar su supervivencia física y psíquica, especialmente en aquellos que han sido expulsados de los márgenes de la sociedad.

Las prácticas colectivas de los sectores populares contribuyen, asimismo, a su emancipación, potenciando su capacidad de configurar nuevas formas de subjetividad política y superando, en consecuencia, las trayectorias de vida a las que se asume se encuentran determinados por su sola pertenencia social.

Cabe destacar, sin embargo, que el viraje en la orientación de las políticas culturales porteñas no sólo afectó a los sectores populares, sino que también se extendió a la gestión de espacios públicos vinculados con la cultura consagrada. Entre ellos resulta paradigmático el caso del Teatro Colón, que entre fines de 2010 y principios de 2011 ocupó el centro del debate por el conflicto desatado en torno a su preservación entre los músicos y técnicos y los funcionarios de gobierno encargados de su mantenimiento.

Sobre los imaginarios colectivos y el uso del lenguaje

Todo proyecto político se sustenta sobre la base de dos ejes que contribuyen a la consolidación en el imaginario social de las ideas que pregona: la identidad y los valores culturales asociados a ella, contemplados en el mito 
de gobierno. Este concepto comprende las aspiraciones propias de los gobernantes respecto de su gestión, y se orienta a generar en la ciudadanía un sentimiento de apropiación de tales ideales, impulsando el acompañamiento de la sociedad hacia los objetivos que el gobierno proyecta. (Riorda, 2006, pp. 62-66) La capacidad de asociación de un proyecto político con determinados valores resulta determinante para lograr la aceptación de las políticas implementadas, así como de todas las decisiones gubernamentales. Su correcta comunicación contribuye a incrementar el nivel de consenso en la ciudadanía acerca de las decisiones de gobierno. El potencial discursivo de los funcionarios, así como de los voceros a cargo del manejo de sus apariciones públicas, debe desarrollarse en función de su alineamiento con el mito de gobierno concebido. Construir un mito de gobierno implica erigir en torno a una gestión un sistema de valores que contribuyen a su legitimación mediante construcciones simbólicas de las que el ciudadano se apropia para interpretar su propio entorno e intervenir en él. Se trata de un intento sistemático de cimentar las mismas palabras y los mismos símbolos en los ciudadanos, mediante la reiteración, en el uso discursivo, de los grandes postulados rectores del proyecto y los valores que pregona.

El análisis del lenguaje adquiere aquí una significación fundamental si se consiente en afirmar, con Castoriadis, que las representaciones de las sociedades, aquellos imaginarios en torno a los cuales hay un consenso establecido -y compartido al menos por la proporción mayoritaria de un grupo social-, se instituyen en y por el lenguaje.

La institución del mundo común es necesariamente en cada momento institución de lo que es y no es, de lo que vale y no vale, así como de lo que es factible o lo que no lo es, tanto "fuera" de la sociedad (...) como "dentro" de ella. En tanto tal, debe necesariamente ser para la sociedad también "presencia" del no ser, de lo falso, de lo ficticio, de lo simplemente posible, pero no efectivo. Mediante la sinergia de todos estos esquemas de significación es como se constituye la "realidad" para una sociedad dada. (Castoriadis, 2007, p. 537) La introducción de un discurso político centrado en valores de desigualdad y exclusión, tendiente a reforzar el imaginario de peligrosidad de los sectores vulnerables y enaltecer el rol del buen ciudadano, es institución de lo que es digno de ser beneficiado con el amparo estatal y de lo que no es merecedor de estas políticas públicas. Es presencia e intervención en el espacio público de ciertos grupos y ausencia -por ocultación y exclusión- de otros.

En sus comunicaciones cotidianas, y ante los conflictos que se desatan tanto en el ámbito de la ciudad como en el plano nacional, Mauricio Macri enfatiza en la necesidad de construir canales de diálogo que permitan lograr un acuerdo entre las partes y disipar los antagonismos sociales. En su intento de autoconstrucción de una imagen de pacificador ante los conflictos, pregona la necesidad de desarrollar la tolerancia, advirtiendo acerca de los problemas que una extrema ideologización podría generar, especialmente si se trata de sectores juveniles.

Subyace a esta concepción de la política una visión de los antagonismos como algo negativo que debe superarse para garantizar el progreso de la sociedad hacia una mayor democratización. La sociedad se vislumbra como una empresa cuyo crecimiento dependerá del cumplimiento de un conjunto de parámetros racionales de efectividad, asignando los recursos disponibles a las áreas estratégicas que garanticen un reintegro en términos de rentabilidad. El Estado, ineficaz y corrupto, se opone al modelo empresarial de gestión política. El discurso a-político del gobierno macrista es político en tanto intenta, desde un relato ascético que enfatiza la eficiencia y la gestión por resultados, supuestamente alejado de la corrupción que se asume 
inmanente a la práctica política entendida como conflicto de intereses, imponer una nueva forma de comprender la política en torno al cual se crea un sentido común que contribuye a su legitimación.

Este discurso fuertemente político de la antipolítica ha logrado construir un nuevo sentido común, borrando el antagonismo constitutivo de visiones o proyectos colectivos En ese marco (...) el componente político de la política (...) cedió su terreno en pos de un nuevo mundo desideologizado, consensual y armónico, que también pretendía llevarse consigo (...) a la historia y a la capacidad inherente de acción social transformadora y crítica del sujeto político. Esta despolitización discursiva, favorecida por el accionar político de las empresas concentradas de medios y sus "intelectuales orgánicos", le permitió al neoliberalismo hegemonizar el espacio público, al tiempo que despolitizaba a la propia ciudadanía. (Fair, 2012, p. 14).

La persistencia de este imaginario neoliberal, oculto tras el disfraz de la defensa de la reconciliación entre los sectores sociales en pugna, significa la negación de la política, no sólo en términos discursivos, sino sobre todo en términos prácticos. Implica negar la existencia de luchas históricamente constituidas en torno a la capacidad de construir e imponer un sentido común legitimado de la propia cosmovisión. Es por ello que resulta importante comprender el sistema mediático nacional como una arena de luchas.

El sistema mediático argentino como campo de fuerzas

En función de la progresiva concentración mediática que se ha suscitado en los últimos treinta años en el escenario argentino como consecuencia de la aplicación sistemática de políticas de privatización que beneficiaron a grandes corporaciones de capitales nacionales y extranjeros, y cuyo centro de operaciones se ubica en la ciudad capital, es posible trasladar el análisis expuesto en este escrito sobre Buenos Aires a la totalidad del espectro mediático nacional.

En este contexto es que resulta preciso comprender el campo mediático como una arena de luchas, según lo entiende Bourdieu, entre la ortodoxia, compuesta por los defensores de una lógica mercantilista de las comunicaciones, y la heterodoxia, constituida por quienes intentan subvertir las reglas de juego y proponer un modelo comunicacional que promueva la participación y la inclusión social, la deshomogenización del sistema mediático y la proliferación de medios y canales que permitan cristalizar la multiplicidad de opiniones y puntos de vista que coexisten en una sociedad.

Como ámbito social estructurado, el campo periodístico ejerce un rol predominante en el mundo social debido a que detenta un monopolio de hecho sobre los instrumentos de producción y de difusión en gran escala de la información y, a través de estos instrumentos, sobre el acceso de los simples ciudadanos pero también de otros productores culturales, sabios, artistas, escritores (...) 'el espacio público', es decir, la gran difusión. (Bourdieu, 1996) De lo antedicho se desprende la necesidad de analizar las circunstancias coyunturales de la actualidad argentina que obligan a revisar el impacto que los medios de comunicación, en tanto instrumentos de cohesión utilizados por la ciudadanía para inteligir la complejidad que la rodea, promueve sobre la formación de pensamientos, estereotipos y representaciones. En toda organización social se advierte la coexistencia de un orden -hegemónico- y una diversidad de órdenes -alternativos- que despliegan estrategias conducentes a la preservación o la subversión de las reglas de juego de ese campo, estableciendo una lucha constante por imponer y legitimar un discurso afín que permita justificar la propia cosmovisión de cada grupo. 
En efecto, Bourdieu (1977) atribuye al discurso la capacidad de dotar de reconocimiento simbólico a las prácticas sociales, en tanto es capaz de "hacer ver y de hacer creer, de confirmar o de transformar la visión del mundo, y por ello, la acción sobre el mundo" (p. 71). Las luchas simbólicas motivadas por el deseo de imponer, a través del discurso mediático, visiones de la sociedad argentina que resulten legitimadas no sólo por sus públicos consumidores sino por los ciudadanos de la ciudad y, por el potencial de propagación que asume su discurso, de todos los rincones del país en los que operan estos grupos, convierten al sistema mediático en un campo de fuerzas en permanente disputa.

El campo mediático argentino -constituido como tal en el siglo XIX-sufrió una profunda transformación a partir de la aprobación de la Ley N²2.285 de Radiodifusión dictaminada por la dictadura cívico-militar en 1980, de la cual se derivó una rotunda escisión entre aquellos que pugnaban por la instauración de una economía neoliberal que tornara posible la disposición de los medios al servicio de las autoridades gubernamentales y las élites hegemónicas, y los que proponían al Estado para ofrecer un servicio orientado a la ciudadanía. Esta legislación sufrió una serie de modificaciones que, con la llegada de la democracia en 1983, tornaron posible la ilusión de convertir a los medios de comunicación en un cuarto poder con capacidad efectiva de intervenir en el curso de los acontecimientos nacionales, rol que las empresas mediáticas ejercieron a la perfección, tras el disfraz de la transparencia, la neutralidad y la objetividad periodística.

Si bien desde la irrupción del primer periódico en la ciudad de Buenos Aires - La Gaceta de Buenos Aires de Mariano Moreno en 1810 - es posible advertir una intencionalidad política ligada a la publicación de medios, no es sino hasta la aprobación de la Ley de Radiodifusión que se advierte la conformación de un campo de luchas profundamente atravesado por ideologías partidarias y una clara intencionalidad de trasladar el poder estatal a corporaciones privadas.

Los medios de comunicación comienzan a ocupar un rol en la sociedad argentina -así como en la región latinoamericana y en todo el mundo- que los convierte en depositarios de un complejo entramado de significaciones sociales que contribuyen a su consolidación como instituciones naturalizadas -que, como tal, no son sometidas a discusión-. Esto les confiere el poder de perpetuar el orden social mediante la propagación de valores y discursos afines a las necesidades del sistema neoliberal, potestad que ejercen gracias a su capacidad de reproducción sistemática en todos los medios, soportes y canales de comunicación interconectados a nivel nacional.

Bourdieu llama inconsciente cultural a la forma en que los hombres participan de los acontecimientos de su época, revelando su pertenencia a una sociedad en la que ciertos cánones culturales resultan hegemónicos, formando habitus que producen y reproducen el orden social, confirmando la veracidad de los mensajes emitidos.

La misión homogeneizante y uniformadora de las corporaciones mediáticas no se revela como tal en el discurso que pugna por su legitimación. Ello se hace evidente en otras instituciones de la sociedad más arcaicas y estudiadas en mayor profundidad como la escuela, que asume como su tarea la promoción de la emancipación intelectual por medio del aprendizaje, cuando su principal meta es asegurar la conservación del orden establecido. En efecto, la institución escolar constituye una de las principales instituciones que detentan el monopolio legítimo de la producción de sentido común, de conocimientos comunes, de un lenguaje, de un pensar y un sentir homólogos. A través del otorgamiento de títulos oficiales que transfieren prestigio y 
reconocimiento social a quienes los poseen, ejercen una diferenciación social que priva a los poseedores de estos títulos de reconocerse como contendientes de la lucha simbólica, para homogeneizarlos detrás de los cánones consagrados. (Bourdieu, 1988, p. 138) Un rol análogo ejercen las comunicaciones en el nuevo contexto mundial desde el ocaso del siglo XX, constituyéndose en instrumentos estratégicos para la conservación del poder político. Durante el menemismo, el mapa mediático sufrió una reconfiguración tendiente a consolidar las modificaciones introducidas en etapas posteriores, especialmente tras el decreto 1005/99 firmado meses antes de finalizar su segundo mandato, que permitió la radicalización del proceso de concentración mediática mediante su encausamiento por vías legales.

Este decreto permitió, en principio, el ingreso de capitales extranjeros para los empresarios de aquellos países con los que la Argentina había firmado tratados de reciprocidad, al mismo tiempo que autorizó la ampliación del número de licencias de cuatro a veinticuatro, operación que estimuló la constitución de grupos multimediáticos con pocos operadores.

Asimismo, amplió la presencia publicitaria en la programación de televisión y radio de unos pocos minutos a franjas de tres a seis horas. Autorizando las cadenas permanentes de transmisión brindó además a los operadores la oportunidad de programar un mismo producto para todo el país para su difusión simultánea, y amparando la transferencia de licencias asestó el golpe final a la ilusión de lograr un sistema de medios públicos facilitando la compra-venta de medios para los sectores privados. (Giniger, 2007) Las reformas mediáticas neoliberales no sólo provocaron la reducción de los canales de participación a vastos sectores de la población argentina, negándoles la posibilidad de acceder a una pluralidad mediática e informativa que permita expresar la pluralidad de posturas y visiones de mundo. La mercantilización de la comunicación convirtió a los medios de potenciales aliados de la ciudadanía en procesos de emancipación y transformación, en socios comerciales de los grupos de poder que aspiran a conservar, en el campo mediático, su rol hegemónico.

En su emblemático artículo titulado Sobre la televisión, Bourdieu efectúa un análisis del campo televisivo combinando aspectos microsociales, vinculados al accionar de los periodistas en tanto agentes sociales constituidos a través de esquemas de percepción, pensamiento y acción proprios de dicho campo, con cuestiones macrosociales, concernientes a los mecanismos globales de estructuración del campo periodístico.

En efecto: El mundo del periodismo es un microcosmos que tiene sus leyes propias y que se define por su posición en el mundo global, por sus atracciones y sus rechazos respecto de otros microcosmos. Decir que es autónomo, que tiene su propia ley, es decir que lo que pasa allí no puede ser comprendido de una manera directa a partir de factores exteriores. (Bourdieu, 1996) En consecuencia, para comprender el campo periodístico es preciso incorporar el análisis de las relaciones de fuerza objetivas que se establecen entre los diferentes canales de televisión, periodistas y medios que no son visiblemente perceptibles ni por los espectadores ni por los propios agentes sociales que operan en este microcosmos. Estas relaciones de fuerza configuran la estructura objetiva del campo periodístico que, aunque invisible, puede tornarse manifiesto observando la partición del mercado, el pelo relativo de cada anunciante y el capital que resulta legitimado en función de su dependencia de los dictámenes del mercado.

Si bien para Bourdieu todos los campos de la producción cultural se encuentran regidos por una lógica comercial, el periodístico es mucho más dependiente de las regulaciones económicas, fenómeno que torna decisiva la inclusión de las mediciones de rating en la producción de contenidos para soportes y medios de 
información. Esta dependencia a las fuerzas externas del mercado le generan un sometimiento desmedido al plebiscito permanente no sólo de sus socios inversores, sino también de la audiencia, sumisión que resulta mucho más significativa que en el ámbito político.

\section{Reflexiones finales}

La investigación de los efectos que los medios masivos de comunicación suscitan en el imaginario social de los distintos grupos ciudadanos en los que se insertan y que, a su vez, le sirven de marco de actuación, ha sido motivo de análisis de diversos autores desde los años '70, momento en el que comienza a surgir un interés cada vez mayor entre los teóricos de la comunicación por demostrar que estos aparatos eran responsables de muchas de las transformaciones sociales acaecidas en el seno de dichas sociedades.

En efecto, tal situación sufrió un crecimiento exponencial a lo largo de los años sucesivos, producto de la irrupción intempestiva de estos instrumentos en la cotidianeidad de las personas, con su consecuente contribución a la reducción, de manera proporcional, de la capacidad de criticidad de los sujetos ante los sucesos relatados desde los discursos mediá- ticos dominantes en cada momento.

Ello permitió vislumbrar una marcada incidencia de los mass media en los ámbito político, cultural y social, por su capacidad de inmiscuirse en la vida cotidiana de las personas como un objeto más de su elección, determinando no sólo qué opinar, sino sobre qué cuestiones hacerlo. Sin embargo, algunas de las teorías que atribuían a los medios masivos un efecto directo e incuestionable sobre las decisiones y conductas de las personas han sido hondamente criticadas por su interpretación mecanicista del devenir social, reforzada por la identificación de lo popular con la irracionalidad y la pasividad. En este plano se ubican las reflexiones de teóricos latinoamericanos que recuperan la capacidad de respuesta de los actores sociales ante el influjo comunicativo de las grandes corporaciones mediáticas, desarrollando estrategias de rechazo, reconstrucción e incorporación de aquellas concepciones que resultan afines a sus motivaciones e intereses personales. No se trata de atribuir a los sectores dominantes un poder inmanente y perpetuo sobre la conducta de los ciudadanos, ni tampoco de atribuir a los actores sociales una capacidad de resistencia intrínseca.

En el marco de este escrito se sostuvo que el innegable poder de influencia que los medios masivos de comunicación detentan en las sociedades en las que se insertan, no sería motivo de conflictividad si la finalidad rectora de la actividad comunicativa persiguiera el propósito de brindar un servicio comprometido con la ciudadanía en su labor informativa, en lugar de regirse por intereses exitistas y economicistas orientados al mero incremento de su rentabilidad.

En efecto, su capacidad de ofrecer marcos de referencia desde los cuales los actores sociales comprenden su cotidianeidad y aprehenden el mundo social que se les presenta como un objeto ajeno -a pesar de ser un producto de su interacción-, da cuenta de su vigorosa influencia.

Analizar el lenguaje mediático no es sólo pensar una forma de comunicación instrumental que un medio utiliza para informar mecánicamente a la población, sino que implica imaginar una forma de vida, un conjunto de prácticas sociales, porque el lenguaje es una forma de vida que alude a actividades humanas reglamentadas que orientan no sólo el pensamiento, sino, consecuentemente, la acción social. (Wittgenstein, 2008) La relación intrínseca entre juegos de lenguaje y formas de vida que plantea Wittgenstein indica que las prácticas sociales 
representan espacios en los que se construyen las significaciones colectivas acerca del mundo circundante, a través de la producción de palabras y conceptos que permiten a los sujetos comprender la realidad valiéndose de las mismas herramientas.

En efecto: La relación entre los juegos de lenguaje y las formas de vida es interna y sustancial. Constituye el marco de referencia en función del cual adquieren significado las palabras, compuesto por los hábitos, costumbres e instituciones. Estos son los lugares o instancias en los que, en una sociedad, se construyen los significados. (...) El lenguaje es el medio a través del cual los hombres articulan y efectivizan sus modalidades de acción e interacción. Pero, además, a través del lenguaje los hombres interpretan y legitiman estas modalidades. (Rivera, 1996) En este sentido, el lenguaje no es nunca un instrumento completamente en manos de los actores de cuyo uso podría derivarse una democratización de las comunicaciones, ni tampoco una herramienta a disposición de los grupos dirigentes y empresas mediáticas para canalizar, directamente y sin obstáculos, a una audiencia homogénea que responde unilateral y pasivamente a sus designios.

Al analizar el discurso mediático -y efectuar una crítica, como se intentó en este escrito-, ambas dimensiones, la del actor y la de las instituciones hegemónicas, deben ser consideradas. Pero no en tanto términos dicotómicos y elementos en tensión, sino en tanto relaciones de lucha que se establecen entre distintos actores sociales orientados hacia la conservación del orden establecido -la homogeneización del sistema mediático argentino, el sostenimiento de una agenda temática centralista, la ficcionalización de la política y la lógica mercantilista de la comunicación gubernamental-, o la subversión de las formas actuales de configuración de la actividad política y, con ello, la comunicación que de aquella se deriva. El análisis genético de las instituciones hegemónicas del sistema mediático nacional permite dar cuenta de la coexistencia de discursos antagónicos que configuran prácticas sociales reguladoras de ese campo. La neutralidad, la objetividad y el innegable papel de portavoces de la verdad que se le atribuye a los medios de comunicación forman parte del entramado de representaciones e imaginarios que se construyen en torno a la práctica periodística.

Estas representaciones configuran -y son configuradas por- el campo periodístico, sus leyes de funcionamiento y las características inherentes a su constitución. La dependencia de este campo a la lógica mercantilista determina su mayor disposición a regular el ejercicio periodístico según los dictámenes del mercado, priorizando los índices de rating y el apoyo de mayores auspiciantes en detrimento de la práctica comunicativa.

La expansión a nivel mundial de políticas neoliberales delineadas por Estados Unidos para sostener y potenciar sus intereses tras el fin de la Guerra Fría, y su introducción en la estructura gubernamental de los países latinoamericanos, constituye una de las principales estrategias delineadas por el imperio para impulsar las necesarias modificaciones del campo mediático -argentino y de otras naciones sudamericanas-, generando su adecuación a las reglas de juego de los emporios multinacionales que operan en el mundo.

Asimismo, la penetración de la lógica economicista en todas las esferas de la sociedad es responsable de la pérdida de autonomía del campo mediático y la introducción de modificaciones radicales en la comunicación política que han convertido a los medios, soportes y canales contemporáneos en meras herramientas de propaganda de los poderes de turno. La utopía de la emancipación latinoamericana y el emblema del compromiso ciudadano fueron gradualmente sustituidos por el paradigma del ciudadano apático a la participación y asumidamente apolítico que observa el juego público desde la comodidad de su hogar como un 
espectáculo interminable mediatizado por un conjunto de actores expertos que exigen su intervención sólo cuando su carrera política corre riesgo de declinar o se acerca a su fin.

Conocer los orígenes y reconstruir la génesis histórica del sistema mediático argentino, reconociendo en él su carácter de construcción social orientada a preservar un orden establecido en un contexto histórico determinado, contribuye a desnaturalizar su presencia en la sociedad y liberarse de las ataduras que su hegemonía cultural impone.

Iniciar esta empresa implica, asimismo, identificar la relación de este sistema con el campo político advirtiendo las formas de violencia simbólica que, mediante su intervención, las autoridades gubernamentales ejercen sobre la ciudadanía mediante el despliegue de dispositivos culturales que imponen un paradigma comunicativo y un ideal de ciudadano adaptado a sus necesidades de conservación del poder.

La estrecha vinculación entre estos campos se advierte con mayor claridad en la emergencia de disciplinas como el Marketing político, así como en la introducción de técnicas y herramientas provenientes del ámbito económico en la práctica periodística para evaluar la calidad de las informaciones emitidas y efectuar una canalización temática conducente al logro de una mayor rentabilidad.

Si bien resulta innegable que los medios de comunicación son, desde su surgimiento, herramientas políticas creadas para fomentar una ideología, apoyar un partido político o promover la candidatura de un funcionario, no es sino hasta la consolidación de la doctrina neoliberal a nivel mundial que la utopía de la información pública halla limitadas sus reales posibilidades de concreción.

La inserción de la racionalidad economicista en la comunicación, así como en el uso que de ella hacen políticos y ciudadanos, ha contribuido a la despolitización de la sociedad civil, transfiriendo la responsabilidad por la información pública a las corporaciones mediáticas que operan en el escenario nacional.

Atravesados por una lógica netamente mercantilista, los medios masivos de comunicación han promovido la cristalización de imaginarios de exclusión e individualismo mediante el enaltecimiento del ciudadano apolítico y la reproducción de lógicas dicotómicas en términos de deseable-indeseable, vida digna de ser vivida y nuda vida.

La excesiva concentración mediática, con la consiguiente homogeneización del discurso y la espectacularización de la política, los políticos y el discurso político, señalan el triunfo de la doctrina neoliberal en la comunicación pública, reduciendo la pluralidad y diversidad de contenidos y reproduciendo saberes conducentes a la legitimación del orden establecido. La tematización periodística se convierte en tematización social, excluyendo de la esfera informativa aquellos acontecimientos que desafían el relato consolidado, invisibilizando así una multiplicidad de sucesos y actores que quedan relegados a los márgenes de la sociedad.

El proceso de privatización de las comunicaciones que se inició durante el primer gobierno menemista, constituyó un punto de inflexión definitivo para trastocar el ideal de ciudadano comprometido y participativo, reemplazándolo por un modelo de ciudadano espectador del juego político. Los medios ya no se dirigen a su audiencia como un conjunto de ciudadanos deseosos de ser informados, sino a una masa de consumidores actuales y potenciales- y espectadores de cuya intervención se benefician inversores y auspiciantes. Este 
proceso experimentó un crecimiento exponencial durante la primera administración macrista, dando cuenta de la continuidad de hecho de la doctrina neoliberal en la ciudad más importante del país en términos sociales, económicos, políticos y culturales.

La comunicación política contemporánea, garante y protectora de las sentencias del mercado, promueve sin pudor la reducción de los espacios de participación, negando así no sólo el ejercicio de la ciudadanía y el debate público, sino también la política misma, limitando a su mínima expresión las vías de canalización de las necesidades sociales.

Es menester de este escrito advertir no sólo la incidencia de estas prácticas en el ámbito comunicacional, sino expresar su influjo sobre la conservación de la democracia y el desarrollo de mecanismos de participación ciudadana. La intervención en la esfera pública y la contribución a la toma de decisiones son elementos fundamentales del ejercicio democrático, y los medios de comunicación deberían ser capaces de garantizar el pleno cumplimiento de estas obligaciones ciudadanas brindado un servicio informativo exhaustivo. La conversión de la política contemporánea en una actividad regida por un código visiblemente espectacular, así como de sus canales de comunicación con la ciudadanía, impone una democracia virtual que en la práctica se reduce a la mera emisión del voto durante los períodos electorales, aunque la proliferación de medios y soportes en la esfera pública virtual insista en indicar lo contrario.

La difusión de relatos da forma a la realidad cotidiana, y es por ello que se torna necesario su alineamiento detrás de los ideales inmanentes a la práctica política y los valores democráticos. La participación en la esfera pública no puede verse reducida a la mera emisión del voto durante los comicios y a la mediatización irrestricta de las comunicaciones polí- ticas disfrazadas de emancipación del espacio de discusión.

En este proceso de vaciamiento y banalización de la práctica política, los medios masivos, comprendidos como sistema, cumplen un rol fundamental, en tanto reproducen a diario a través de una multiplicidad de programas, canales y soportes los valores e ideales afines al ciudadano modelo que pregona y requiere la doctrina neoliberal. La proliferación de discursos legitimadores del poder hegemónico los convierte en cómplices y responsables de la negación de la política y su reemplazo por una mordaz caricatura.

La connivencia entre el poder político y el poder mediático -hoy absorbido por el poder económico- contribuye a reforzar el status quo neoliberal, propalando y fortaleciendo la despolitización de la ciudadanía mediante la reducción de los canales de participación y el asentimiento en la aplicación de políticas de restricción de la participación pública.

En este sentido, una última reflexión merece ser incluida: Si la política se refiere, en su mínima expresión, a la construcción del orden, la política democrática se refiere a la construcción de un orden institucional, plural, conflictivo y abierto. Institucional en el sentido de una cultura de solidaridad de procedimientos; plural en cuanto al reconocimiento de sujetos distintos; conflictivo porque acepta diversas relaciones sociales y distintas orientaciones de los actores; y abierto por la incertidumbre intrínseca del juego democrático y de la capacidad de la democracia de innovarse constantemente. (Calderón y Szmukler, 2006, p. 223) En la era de la hipermediatización tecnológica, el uso de los medios de comunicación para lograr el desarrollo de una gobernabilidad democrática, asentada sobre valores de inclusión, pluralidad y reconocimiento de la diversidad resulta, por ello, indispensable en la estrategia política de los gobiernos latinoamericanos. Tanto en el proyecto de generación de 
una ciudadanía social como en la construcción y sostenimiento de una esfera pública abierta y heterogénea capaz de canalizar y viabilizar las necesidades de los ciudadanos de estas latitudes, emancipándolos de las múltiples barreras que mediatizan su intervención.

Referencias bibliográficas

Ansaldi, W. (1995). Gobernabilidad democrática y desigualdad social. En Estudios Sociales. Revista Universitaria Semestral, nº 9, pp. 9-35. Santa Fe.

Ansaldi, W. (2004). Matriuskas de terror. Algunos elementos para analizar la dictadura argentina dentro de las dictaduras del Cono Sur. En Pucciarelli, A. (coord.). (2004).

Empresarios, tecnócratas y militares. La trama corporativa de la última dictadura. Buenos Aires: Siglo Veintiuno Editores.

Ansaldi, W. (2006). El silencio es salud. La dictadura contra la política. En Quiroga, H. y Tcach, C. (comps.). (2006). Argentina 1976-2006. Entre la sombra de la dictadura y el futuro de la democracia. Santa Fe: HomoSapiens. (p. 101).

Asamblea Docente del Distrito Escolar N8 (2011). Si te preocupan los paros docentes en la Ciudad de Buenos Aires, lo mejor es informarse. Disponible en: https://docs.google.com/document/d/1 mldeZ4dyQ9iGleotKzxsFRW0V5C3WW5GNh4Vof6ljw/view?hl=es\&pli=1 Barbero, J. M. (2010). De los medios a las mediaciones: comunicación, cultura y hegemonía, Anthropos Editorial en coedición con la Universidad Autónoma Metropolitana Azcapotzalco, México. (p. 160).

Barnhurst, K., Cordeiro, T. y Sampedro, V. (2003). Mercantilización mediática y ciudadanía. En Revista Reis, 103/03. (pp. 220-221) (p. 234) Becerra, M. y Mastrini, G. (2001). 50 años de concentración de medios en América Latina: del patriarcado artesanal a la valorización en escala. Buenos Aires: Cátedra Políticas y Planificación de la Comunicación. Facultad de Ciencias Sociales. Universidad de Buenos Aires.

Bourdieu, P. (mayo-junio de 1977). Sobre el poder simbólico. En Revista Annales, nº 3.

Bourdieu, P. (1996). Sobre la televisión y El campo periodístico y la televisión. Barcelona: Editorial Anagrama.

Breton, P. (1998). Medios, mediación, democracia. Para una epistemología crítica de las ciencias de la comunicación política. Barcelona: Gedisa. (pp. 356-371).

Castoriadis, C. (2007). La institución imaginaria de la sociedad: el imaginario social y la institución. TusQuets Editores. (p. 537) Castro, E. (2008). Giorgio Agamben: una arqueología de la potencia. Buenos Aires: Jorge Baudino Ediciones, UNSAM EDITA. (p. 61). (p. 62).

Chiriguini, M.C. y Gravano, A. (2008). Apertura a la antropología: alteridad, cultura, naturaleza humana. Buenos Aires: Proyecto Editorial. 
Cicalese, G. y Rinaldi, L. (2006). La invasión de la comunicación institucional al periodismo. Buenos Aires: Centro de Comunicación La Crujía.

Curran, J. (1991). Rethinking the Media as a Public Sphere. (pp. 105-111). Citado en: Sampedro, V. (2000). Opinión pública y democracia deliberativa. Medios, sondeos y urnas. Madrid: Istmo.

Canal 5 Noticias. (Diciembre de 2010). Mauricio Macri Parque Indoamericano. Disponible en: http://www.youtube.com/watch?v=1Jwc_3cWpSI D Andrea Mohr, J.L. (1999). Memoria debida (devida). Buenos Aires: Ediciones Colihue. (p. 69) Debord, G. (1967). La sociedad del espectáculo. París: Buchet-Chastel.

Fair, H. (agosto-octubre 2012). El discurso político de la antipolítica. En Razón y Palabra, Primera Revista Electrónica en América Latina Especializada en Comunicación, $n^{\circ}$ 80. (p. 14).

Forster, R. (enero de 2012). Giro cultural y nuevas formas de ciudadanía. En Revista Veintitrés.

Giniger, L.P. (diciembre de 2007). Legislación y concentración mediática en la Argentina. En La Revista del CCC (versión en línea), n¹. Disponible en: http://www.centrocultural.coop/revista/articulo/11/. ISSN 1851-3263.

Habermas, J. (1981). Historia y crítica de la opinión pública. Barcelona: Gustavo Gili.

Lechner, N. (julio-agosto 1996). La política ya no es lo que fue. En Nueva Sociedad, na 144. Macri atribuyó los incidentes en el Parque Indoamericano a la "inmigración descontrolada". (9 de diciembre de 2010). En TELAM, Agencia de noticias de la República Argentina. Disponible en: http://www.telam.com.ar/vernota.php? idPub=205868\&id=391158\&tipo=N\&dis=1\&sec=1 Raggio, L. y Sabarots, H. (julio de 2012). Políticas públicas en la Ciudad de Buenos Aires dirigidas a juventudes vulnerables. Continuidades y transformaciones en la última década.

En Runa, vol. 33, n¹ (pp. 9-31). Recuperado el 6 de noviembre de 2012. Disponible en: http://www.scielo.org.ar/scielo.php?pid=S1851-96282012000100001\&script=sci_arttext\&tlng=pt Rivera, S. (1996). Ludwig Wittgenstein: hacia una teoría social crítica y transformadora. En: Díaz, E. (Ed.). La Producción de los conceptos científicos. Buenos Aires: Editorial Biblos.

Rouvier, R. (2004). La deuda de la política. Buenos Aires: Corregidor.

Sfez, L. (1999). Internet y los trabajadores. Citado en: Sampedro, V. (2000). Opinión pública y democracia deliberativa. Medios, sondeos y urnas. Madrid: Istmo.

Van Dijk, T. (2001). Critical discourse analysis. Citado en Raiter, A. y Zullo, J. (comp.).

(2008). La caja de Pandora. La representación del mundo en los medios. Buenos Aires: La Crujía. (p. 96) Raiter, A. y Zullo, J. (comp.). (2008). La caja de Pandora. La representación del mundo en los medios. Buenos Aires: La Crujía. (p. 29).

White, R. (2007). Comunicar comunidad. Aportes para una ética de la comunicación pública. Buenos Aires: La Crujía Ediciones. 
Williams, R. (2009). Marxismo y literatura. Buenos Aires: Las Cuarenta.

Wittgenstein, L. (2008). Investigaciones filosóficas. Barcelona: Editorial Crítica.

Bibliografía

Ansaldi, W. (1995). Gobernabilidad democrática y desigualdad social. En Estudios Sociales. Revista Universitaria Semestral, $n^{\circ}$ 9, pp. 9-35. Santa Fe.

Ansaldi, W. (2006). Calidoscopio latinoamericano. Imágenes históricas para un debate vigente. Buenos Aires: Ediciones Ariel Historia.

Barbero, J.M. (2010). De los medios a las mediaciones: comunicación, cultura y hegemonía, Anthropos Editorial en coedición con la Universidad Autónoma Metropolitana Azcapotzalco, México.

Barnhurst, K., Cordeiro, T. y Sampedro, V. (2003). Mercantilización mediática y ciudadanía. En Revista Reis, 103/03.

Becerra, M. y Mastrini, G. (2001). 50 años de concentración de medios en América Latina: del patriarcado artesanal a la valorización en escala. Buenos Aires: Cátedra Políticas y Planificación de la Comunicación. Facultad de Ciencias Sociales. Universidad de Buenos Aires.

Breton, P. (1998). Medios, mediación, democracia. Para una epistemología crítica de las ciencias de la comunicación política. Barcelona: Gedisa.

Castoriadis, C. (2007). La institución imaginaria de la sociedad: el imaginario social y la institución, TusQuets Editores.

Cicalese, G. y Rinaldi, L. (2006). La invasión de la comunicación institucional al periodismo. Buenos Aires: Centro de Comunicación La Crujía.

D Andrea Mohr, J.L. (1999). Memoria debida (devida). Buenos Aires: Ediciones Colihue.

Debord, G. (1967). La sociedad del espectáculo. París: Buchet-Chastel. Díaz, E. (Ed.). La Producción de los conceptos científicos. Buenos Aires: Editorial Biblos.

Forster, R. (enero de 2012). Giro cultural y nuevas formas de ciudadanía. En Revista Veintitrés.

Habermas, J. (1981). Historia y crítica de la opinión pública. Barcelona: Gustavo Gili.

Lechner, N. (julio-agosto 1996). La política ya no es lo que fue. En Nueva Sociedad, $\mathrm{n}^{\mathrm{a}} 144$.

Pucciarelli, A. (coord.). (2004). Empresarios, tecnócratas y militares. La trama corporativa de la última dictadura. Buenos Aires: Siglo Veintiuno Editores. 
Quiroga, H. y Tcach, C. (comps.). (2006). Argentina 1976-2006. Entre la sombra de la dictadura y el futuro de la democracia. Santa Fe: Homo sapiens.

Raiter, A. y Zullo, J. (comp.). (2008). La caja de Pandora. La representación del mundo en los mmedios. Buenos Aires: La Crujía.

Rouvier, R. (2004). La deuda de la política. Buenos Aires: Corregidor.

Sampedro, V. (2000). Opinión pública y democracia deliberativa. Medios, sondeos y urnas. Madrid: Istmo Thuillier, P. (1983). La trastienda del sabio. Barcelona: Editorial Hachette.

White, R. (2007). Comunicar comunidad. Aportes para una ética de la comunicación pública. Buenos Aires: La Crujía Ediciones.

Williams, R. (2009). Marxismo y literatura. Buenos Aires: Las Cuarenta.

3.1. Hacia la construcción de una ciudadanía mediática. Reflexiones sobre la influencia de las políticas neoliberales en la configuración de la comu fue publicado de la página 242 a página284 en Cuadernos del Centro de Estudios de Diseño y Comunicación № 63 